\title{
コーダ波から推定されるリソスフェアの ランダム不均質構造
}

\author{
弘前大学理工学部附属地震火山観測所* 小 菅 正 裕
}

\section{Random Inhomogeneities in the Lithosphere Inferred from Coda Analysis}

\author{
Masahiro Kosuga \\ Earthquake and Volcano Observatory, Faculty of Science \\ and Technology, Hirosaki University, Bunkyo-cho 3, \\ Hirosaki-shi, Aomori-ken 036-8561, Japan
}

(Received November 29, 2000; Accepted February 26, 2001)

\begin{abstract}
Random inhomogeneities in the lithosphere have been investigated through the analysis of coda waves that are thought to be generated by the inhomogeneities. The power spectral density of upper crustal inhomogeneities measured directly using borehole logs obeys power law for a wide range of wavenumber, which is the characteristics of the exponential or the von Kármán autocorrelation function. The methods preferentially used for the coda analysis are phenomenological modeling based on the energy transport theory or stochastic simulation of wave propagation based on the Born approximation in random media. The parameters estimated from the methods are the scattering coefficient and coda attenuation $\left(Q_{c}^{-1}\right)$ of scattering media or the fractional fluctuation of seismic wave velocity and the correlation length of random inhomogeneities. Although the frequency and lapse time dependence of $Q_{c}^{-1}$ has been widely recognized from the numerous works conducted in the last two decades, the physical meaning of $Q_{c}^{-1}$ and its lapse time dependence have not yet been clarified completely. Some recent works tried to understand it by considering layered structures with different values of scattering coefficient and intrinsic attenuation. The estimated range of fractional velocity fluctuation and correlation length is $1-8 \%$ and $0.15-1.0[\mathrm{~km}]$ in the crust and $2-8 \%$ and $1-20[\mathrm{~km}]$ in the upper mantle, respectively. The magnitude of fractional fluctuation shows little difference between the crust and the upper mantle, however, the correlation distance exhibits large difference that reaches one order of magnitude. In addition, the horizontal correlation length is much longer than the vertical one, forming the anisotropic inhomogeneities in the lithosphere. The recent observations of high-frequency teleseismic Pn gave an additional evidence of random inhomogeneities in the upper mantle. Thus the coda methods have great advantage to get stochastic insight into realistic image of the lithosphere.
\end{abstract}

Key words: Random Inhomogeneities, Lithosphere, Coda, Scattering, Autocorrelation function.

\section{§1.はじめに}

地震波の $\mathrm{P}$ 波および $\mathrm{S}$ 波の主要動後には, コーダ波 と呼ばれる位相の不ぞろいな（インコヒーレントな）後 続波群が出現する (Fig. 1). コーダ波の研究は, それが地 球内部に存在するランダムな不均質によって散乱された 波であることの発見 [Aki (1969)] や, PKIKP 波の先駆

*\%036-8561 青森県弘前市文京町 3
波が核一マントル境界近傍での不均質による散乱波であ るとの解釈 [Cleary and Haddon (1972)] をきっかけと して始められた，その後, コーダ波生成モデルの発展や, 不均質媒質中の波動伝播の理論的研究およびシミュレー ション技術の進展によって, コーダ波の性質が明らかに されるとともに, 地球内部の不均質構造の解明が進めら れてきた。

不均質媒質に地震波が入射した場合によ゙のような現象 

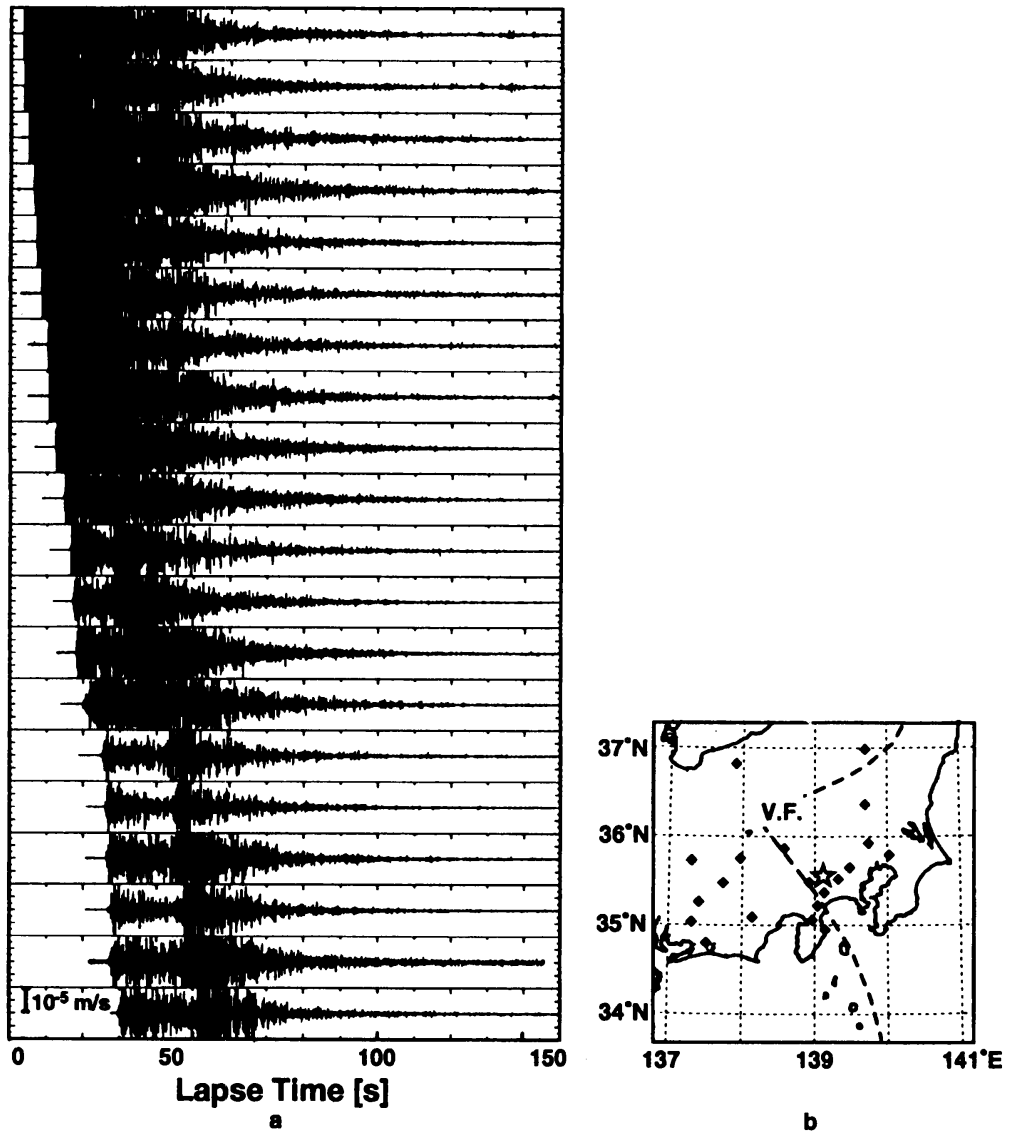

Fig. 1. Horizontal component velocity seismograms of an earthquake with a magnitude of 4.6 and a focal depth of $19.3 \mathrm{~km}$. The epicenter of event and the distribution of stations are shown in the right hand side of figure. After Obara in Sato and Fehler (1998), with permission from SpringerVerlag.

が起こるかは, 不均質のスケール（2.1 で述べる相関距 離) $a$, 地震波の波数 $k$ (波長 $\lambda$ の逆数), および伝播距離 $L$ に依存する [Aki and Richards (1980), Herraiz and Espinosa (1987), 西澤・他 (2001), Wu and Aki (1988 a)]. 波長が $a$ よりも充分に長い $k a<0.01$ のとき，媒質 は有効弾性定数をもつ均質媒質と見なすことができる. 波長が不均質のスケールに近いと種々の散乱の効果が現 れる. 不均質のサイズが波長程度であるときはそれが最 屯顕著で, 高角度の散乱（角度は入射波の進行方向から 測る）が生じ, より波長が短い $k a>1$ のときには前方散 乱が生じる. 波長が不均質のスケールよりも十分に短い $k a>>1$ のときには幾何光学的な扱いができる.この場 合には, 波線理論に基づいて「決定論的な構造」, すなわ ち, 座標の関数として一意に定まる速度值の分布を求め ることができる.したがって, 波長と同程度またはより 短波長の構造は決定論的には決めにくい.このような不
均質構造を本論では「ランダム不均質構造」と呼ぶ。媒 質をランダム媒質として統計的に表現し，確率論的な手 法に基づいて解析することはかなりの成功をおさめてき た. そのため, 散乱波によって推定される不均質構造を 「確率論的構造」ということがある.

ランダム不均質媒質中を通過する波によるエネルギー 伝播を扱う場合, 輻射伝達方程式と呼ばれる積分方程式 が基本方程式となる。この方程式の扱いは上記の $k a$ の 大きさと, 基本方程式に対する近似の度合いによって変 わってくる. 1 次散乱モデルは摄動計算において 1 次の 散乱項までをとったものである. 本論で対象とする地球 内部の不均質構造の推定には, 1 次散乱モデルが多く使 われてきた. それによって推定されるパラメータは散乱 係数とコーダ波減衰 (コーダ Q), または速度ゆらぎの大 きさとゆらぎの相関距離である.

本論では, 地球内部の深さおよそ $100 \mathrm{~km}$ までのリソ 
スフェアについて，コーダ波から推定される不均質構造 を概観する. 上記のパラメータのうち, 散乱係数とコー ダ波減衰は不均質構造そのものを直接的に表すわけでは ないが，それを反映したパラメータである，また，その 推定はこれまでに非常に多く行われてきているので，本 論においても扱うこととする．\$2では地球内部に短波 長不均質構造が存在すると考えられる根拠を詳しく述 べ， § 3 ではランダム不均質構造を仮定したコーダ波生 成モデルを紹介する. §4 ではそのモデルに基づいて推 定された散乱係数とコーダ波減衰について述べる．８5 では一様ランダムな構造では説明できないコーダ波の特 徵に言及する。 §6ではコーダ波の解析から推定された 速度ゆらぎの大きさと相関距離について紹介する．最後 に, これまでの研究成果に基づき, 今後の研究の課題を 挙げる. なお，本論で扱う内容には, Sato and Fehler (1998) を始めとして, 本号の他の総合報告において詳し く解説されている部分あある. それについては各論にお いて紹介するので，興味のある読者はそれらあ参照され たい.

\section{§2. ランダム不均質構造が存在する証拠}

地球内部には様々なスケールの不均質構造が存在す る. Wu and Aki (1988a) は, 地震学的な種々の手法に よって測定された地球内部の不均質の大きさと空間的ス ケールをまとめた. それによると, 空間的な広がりは鉱 物の粒子サイズの数 $\mathrm{mm}$ から大陸の大きさの数干 $\mathrm{km}$ までおよび，その幅は 8 桁にあなる。それれ対して速度 ゆらぎの大きさは構造のスケールにはあまり依存せず, $0.5 \sim 10 \%$ の範囲に分布する.

\section{1 ランダム不均質性の表現}

実際のランダム不均質構造について紹介する前に, ラ ンダム不均質の数学的表現を簡単に示しておこう。速度 一定の均質な弾性体内に速度ゆらぎが重なっている場合

(a) Auto correlation

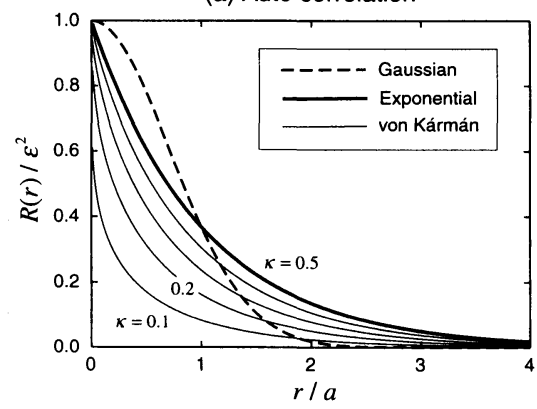

を考える.ゆらぎの平均值は 0 と仮定し，媒質は巨視的 には均質・等方とする。この場合の速度ゆらぎの性質 は, ゆらぎの自己相関関数 $R(\boldsymbol{x})$ で表される.ここで $\boldsymbol{x}$ は空間座標を表す。ランダム媒質を表現するのに用いら れる自己相関関数としては, 次の 3 種類が一般的である [例えば, Frankel and Clayton (1986)].

(1) ガウス型: $R(\boldsymbol{x})=R(r)=\varepsilon^{2} \exp \left(-r^{2} / a^{\mathrm{a}}\right)$

(2) 指数関数型: $R(\boldsymbol{x})=R(r)=\varepsilon^{2} \exp (-r / a)$

(3) フォン・カルマン型:

$$
R(\boldsymbol{x})=R(r)=\left[\varepsilon^{2} 2^{1-\kappa} / \Gamma(\kappa)\right](r / a)^{\kappa} K_{\kappa}(r / a)
$$

ここで $r \equiv|\boldsymbol{x}|, \varepsilon^{2}$ は分布の分散, $a$ は相関距離, $\Gamma$ はガ ンマ関数, $K_{\kappa}$ は $\kappa$ 次の第 2 種変形ベッセル関数である. $\kappa$ は媒質の複雑さを表す指標になっている. フォン・カ ルマン型において $\kappa=0.5$ の場合の自己相関関数は, 指 数関数型の自己相関関数之一致する. (1) (3) の自己相 関関数とそのパワースペクトル密度を比較したのが Fig. 2 である. 自己相関関数の形 (a) を見ると, ラグ $r$ に 対する依存性の違いから，ガウス型の場合は長波長のゆ らぎが卓越するのに対し, 指数関数型やフォン・カルマ ン型はより短波長の不均質性が卓越する. 特にパワース ペクトルで見た場合 (b), 指数関数型やフォン・カルマ ン型のそれは波数の大きいところでは波数のべき乗で表 されることが特徴である. 3 種類の自己相関関数で表さ れる地震波速度のゆらぎを視覚的に表現した図は吉本 (2001) を参照されたい.

\section{2 実測されたランダム不均質性}

地球内部にランダムな不均質構造が存在する直接的な 証拠は,ボアホールにおける検層データからあ得られ る. 速度検層データは, 地震波速度が深さとともに単調 に増加するのではなく， かなり大きな短波長のゆらぎを 含むことを示している. Shiomi et al. (1997) は九州の九 重火山地域における深さ $1700 \mathrm{~m}$ 孔の地震波速度・密度 検層データの自己相関関数を求め, ガウス型よりは指数

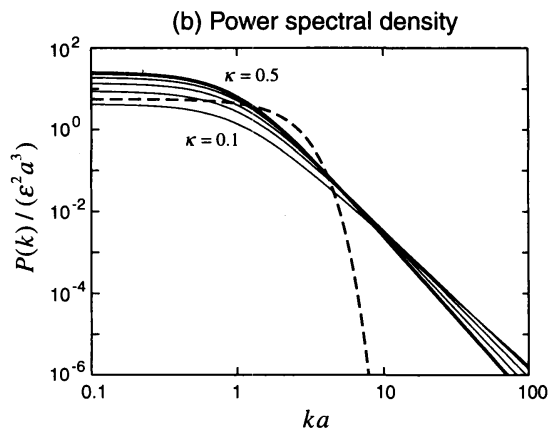

Fig. 2. Plots of auto correlation function (ACF) (a) and power spectral density (b) for three types of random media, Gaussian, exponential, and von Kármán. The curves for $\kappa=0.5$ of von Kármán ACF coincide with those of exponential ACF. 
関数型またはフォン・カルマン型に近いこと, $1 \mathrm{~m}$ から 数百 $\mathrm{m}$ の広い波長域で, $\mathrm{P}$ 波速度のパワースペクトル 密度は波数の - 1.37 乗に比例して減少することを示し た. 同様なべき乗則に従う振る舞いは, ドイッの KTB 深 層ボーリングにおいても知られている [Wu et al. (1994)] KTB 深層ボーリングでは, その後 Holliger (1996), Kneib (1995), Leonardi and Kümpel (1998) が, 深さ 4000 m のパイロット孔と $9000 \mathrm{~m}$ の本孔における帯磁 率・地震波速度・密度などのランダム不均質性を測定し た.これらの研究では長波長のゆらぎの取り扱い法など が若干異なるが，互いに矛盾しない結果が得られてい る. Holliger (1996) によると, $\mathrm{P}$ 波速度検層デー夕から 推定した，フォン・カルマン型の自己相関関数 ((3) 式) を特徴づける $\kappa$ の值は 0.1 と 0.13 である. 彼はさらに, ヨーロッパと北米の 8 本のボーリング孔での $\mathrm{P}$ 波速度 検層デー夕も解析し， $\kappa$ が $0.1 \sim 0.2$ の值をとることを示 した．場所によって地質・岩石が異なってもんが似たよ うな值をとることの解釈として，速度検層に現れる不均 質性は岩石の種類よりはクラックの分布に敏感であるこ とを挙げている. 上記の研究は, 1 本または 2 本のボ アホールでの解析から主として深さ方向に見た場合の不 均質のゆらぎを扱っているのに対して, Dolan et al. (1998) は近接して掘削された 9 本のボアホール（深さ $1000 \sim 1500 \mathrm{~m}$ ）での速度検層データから，速度ゆらぎ の横方向の相関距離が $\mathrm{km}$ のオーダーであることを示 した.

ゆらぎが平均値のまわりに連続的な確率分布をもつの ではなく，離散的な分布をする場合を考察した研究もあ る. Holliger and Levander (1992) は，下部地款の断面 が地表に露出していると考えられるイタリア北部の Ivrea 岩体地域において, 地質図をディジタイズするこ とによって離散的なゆらぎを表現し，その統計的な性質 を抽出した。 その結果, 岩質の不均質性は $\kappa$ が 0.3 の フォン・カルマン型で表されることがわかった。 また， 相関距離は水平方向で 550〜 750 m, 鉛直方向で 135〜 $200 \mathrm{~m}$ であった，彼らはさらに，上部地款の岩体と考え られるスコットランドの Lewisian 片麻岩体 [Levander et al. (1994a)] やイタリアの Strona-Ceneri 帯 [Holliger and Levender (1994)] などについても不均質性を 推定した. Lewisian 岩体での不均質性は $\kappa$ が 0.22 0.45 のフォン・カルマン型で表され，ゆらぎの相関距離 は水平方向で $111 \sim 244 \mathrm{~m}$, 鉛直方向で 38 133 $\mathrm{m}$ で あった。

これまで紹介した研究に示されるように，検層データ や地質データが示す不均質性の自己相関関数はフォン・ カルマン型で表現でき，それを特徵づける
〜 0.3 の値をとることが多い. また，鉛直方向の相関距 離が水平方向よりあ短く，異方的な構造となっているこ とも明らかになった。このような地壳・マントル構造の イメージは 6.4 においても取り上げる.

\section{3 地震波に現れるランダム不均質性}

Fig. 1 に示されるようなインコヒーレントなコーダ波 の存在は地震記象を複雑にしているが，コーダ波のエン ベロープ (包絡線) 形状には共通した性質がある. Fig. 1

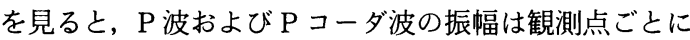
異なるが， S コーダ波振幅の時間減衰の割合や振動継続 時間はほぼ一定である．近地地震の S コーダ波のこのよ うな特徴は, Aki and Chouet (1975) によりまとめられ た. 観測点間における地震波スペクトルの相違がないこ と, 地震動継続時間が震央距離や方位角にはあまり依存 しないこと，パワースペクトルは地震の発震時 (origin time) からの経過時間の関数として減衰すること, S コーダ波は震源方向から到来する平面波ではないこと [例えば, Aki and Tsujiura (1959)］などは，後述の散 乱モデル構築の基礎になった。 また，コーダ波の励起は 観測点の地盤条件に依存することや，S コーダ波の振幅 が S 波の地盤特性と良い相関を示すこと [Tsujiura (1978)]は，S コーダ波が主として S 波から構成されて いることを示している.

\section{§3. ランダム不均質媒質中でのエネルギー伝播}

\section{1 モデルの概観}

ランダム不均質媒質中の波動伝播を近似的に扱うため に，リソスフェア中に点状の散乱体が一様・ランダムに 分布する場合のエネルギー伝播を考えることが提案され た. Aki and Chouet (1975) はこのようにモデル化した 散乱波のエネルギーを重ね合わせることによって，上記 のコーダ波の特徴が定量的に説明できることを示した。

同様なモデルとしては，Sato (1977) や Frankel and Wennerberg (1987) などによるものがあり，現象論的 モデルと呼ばれる場合がある，現象論的モデルを規定す るパラメータは散乱強度とコーダ波減衰である。このう ち, Aki and Chouet (1975) や Sato (1977) のモデルは 2 次以上の高次散乱は無視しているので, 1 次散乱モデ ルと呼ばれる。これは散乱が弱い場合や経過時間があま り大きくない場合は良い近似になるが，コーダ波の後半 部分では多重散乱の影響を無視できなくなる，Kopnichev (1975) や Gao et al. (1983) は, 1 次散乱モデルの 拡張としての多重散乱モデルを考えたが，これらのモデ ルではエネルギーが保存されないという難点があった.

多重散乱の系統的な取り扱いは，輻射伝達理論 (radiative transfer theory) またはエネルギー輸送理論 
(energy transport theory) と呼ばれる方法に基づいて 行われるようになった. ランダム不均質媒質中を伝播す る波のエネルギー輸送は, 輻射伝達方程式と呼ばれる積 分方程式が基本方程式となる. 従来の 1 次散乱モデル は, この基本方程式の一次捸動項のみを用いたものであ る. 他分野において導入された輻射伝達理論を地震波の 散乱問題に最初に導入したのは, Wu (1985) および Wu and Aki (1988b) である. 地震波の場合は, 震源からの インパルス的なエネルギー輻射に起因する, 非定常な散 乱を扱う点が特徴である. その後, この理論に基づいた 非定常散乱問題の定式化は Shang and Gao (1988), Zeng et al. (1991), Sato (1993, 1994) などによって行わ れてきた. Gusev and Abubakirov (1987) および Hoshiba (1991) は, モンテカルロ法を用いて輻射伝達方程 式を時間領域で数值的に解いた，輻射伝達理論について は本号の干場 (2001) において詳しく紹介されている.

本論で扱うリソスフェアのランダム不均質構造の推定に は, 現象論的モデル, 中でも 1 次散乱モデルがよく用い られてきたので，それについてだけ簡単に紹介してお $<$.

\subsection{1 次散乱モデル}

Aki and Chouet (1975) は簡単のために震源と観測点 が同じ位置にあるとし, 実体波の 1 次後方散乱による コーダ波エネルギー密度を次のようにモデル化した。

$$
E^{1}(\boldsymbol{x}=0, t)=\left[\left\{W g_{\pi} H(t)\right\} /\left\{2 \pi V_{0}^{2} t^{2}\right\}\right]
$$

$$
\exp \left(-Q_{C}^{-1} \omega t\right)
$$

らの全放射エネルギー， $g_{\pi}$ は後方散乱係数（散乱角 $\pi$ の 方向の散乱係数), $V_{0}$ は地震波速度, $H(t)$ は階段関数, $t$ は震源時 (origin time) からの経過時間, $Q_{C}^{-1}$ はコーダ 波の振幅減衰を表す現象論的なパラメータ（コーダ $\left.Q^{-1}\right)$ である. 幾何減衰の効果は $t^{-2}$ の項に含まれてい るので, $Q_{C}^{-1}$ は幾何減衰以外の効果による振幅減衰を表 す.

震源と観測点が離れている場合について, 実体波の等 方散乱（散乱体に平面波が入射した場合に，どの方向に あ同じ割合で散乱される）を仮定したモデルはSato (1977) が導いた。この場合は

$$
\begin{aligned}
E^{1}(\boldsymbol{x}, t)= & {\left[\left\{W g_{0} K\left(V_{0} t / r\right) H\left(V_{0} t-r\right)\right\} /\left\{4 \pi r^{2}\right\}\right] } \\
& \exp \left(-Q_{C}^{-1} \omega t\right)
\end{aligned}
$$

と表される（1 次等方散乱モデル）。ここで $g_{0}$ は全散乱 係数, $H$ はステップ関数で, $K$ は次のような関数であ る.

$$
K(x)=(1 / x) \ln \{(x+1) /(x-1)\},(x>1)
$$

1 次等方散乱モデルは, 震源時からの経過時間が $\mathrm{S}$ 波走 時の 2 倍を超えるような条件下では, 1 次後方散乱モデ ルと等価になる.

表面波の散乱については Kopnichev (1975) が次のよ うな式を導いた。

$$
\begin{aligned}
E^{1}(\boldsymbol{x}, t)= & {\left[\left\{W g_{0} H\left(V_{0} t-r\right)\right\} /\{2 \pi r\}\right] } \\
& \left\{\left(V_{0} t / r\right)^{2}-1\right\}^{-1 / 2}
\end{aligned}
$$

表面波と実体波の場合を比較すると $t$ への依存性が異な るが，これは幾何減衰の違いを反映している.

ここで $E^{1}$ は 1 次散乱のエネルギーを表し， $W$ は震源か

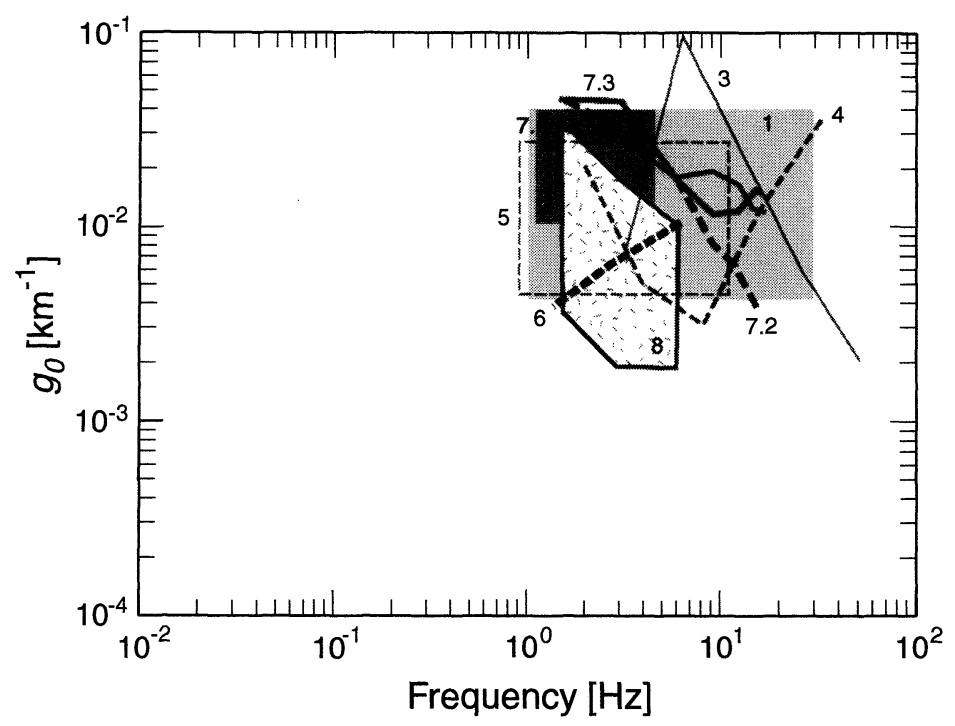

Fig. 3. Total scattering coefficient $g_{0}$ versus frequency from regional measurements made throughout the world [after Sato and Fehler (1998) with permission from Springer-Verlag]. Numerals represent different regions. 


\section{§4. 散乱係数とコーダ波減衰の測定}

§3 で紹介したモデルを用いて，コーダ波を特徴づけ るパラメータである全散乱係数 $\left(g_{0}\right)$ とコーダ波減衰 $\left(Q_{C}^{-1}\right)$ の推定が世界各地で行われてきた. 散乱係数は単 位体積当たりの散乱の強さを表し， $Q_{C}^{-1}$ はコーダ波振幅 の指数関数的な時間減衰を特徵づける. 両者の測定結果 は Herraiz and Espinosa (1987), Matsumoto (1995), Sato and Fehler (1998) などにまとめられているので, 興味のある読者はこれらも参照されたい.

\section{1 散乱係数の測定}

1 次等方散乱モデルに基づく $g_{0}$ の測定は, 関東地 方 [Sato (1978), Aki (1980)], 長野県西部 [Kosuga (1992)], カナダの New Brunswick [Dainty et al. (1987)], 中央ギリシャ [Baskoutas (1996)] などで行わ れてきた，輻射伝達理論に基づく Multiple Lapse-Time Window 解析（MLTW 法）からの測定は, 関東・東海 [Fehler et al. (1992)], 中央カリフォルニアやハワイ [Mayeda et al. (1992)], 日本 [Hoshiba (1993)] よ゙での 例がある. MLTW 法は, 経過時間の短いウィンドウの コーダ波エネルギーには内部減衰の寄与が大きく, 経過 時間の大きなウィンドウでのコーダ波エネルギーには散 乱減衰が効くことを利用して，いくつかの経過時間ウィ ンドウについてコーダ波エネルギー密度の空間分布を求 め, 両減衰および散乱係数を推定する方法である. Abubakirov and Gusev (1990) はモンテカルロ法によるシ ミュレーションから, カムチャツカでの平均自由行程 を, Gusev and Abubakirov (1999) は同地域の散乱係 数の深さ分布を推定した. Nishimura (1996) は長周期 $\mathrm{P}$ 波のパーティクル・オービットの解析から $g_{0}$ を推定 した.

これらの結果をまとめると (Fig. 3), 1〜 30 Hz での $g_{0}$ はオーダーとして $10^{-2}\left[\mathrm{~km}^{-1}\right]$ の值をとる.ただし，測 定値は $2 \times 10^{-3} \sim 10^{-1}\left[\mathrm{~km}^{-1}\right]$ の間に分布し，ばらつき はかなり大きい，また，周波数依存性が認められる場合 ああるが，後述する $Q_{C}^{-1}$ のような一定の傾向は見られ ない.

\section{2 コーダ波減衰の測定}

§3 で示したように, コーダ波振幅の減衰曲線は発震 時からの経過時間の関数として表され，特に経過時間が $\mathrm{S}$ 波走時の 2 倍を超えると，コーダ波の減衰曲線は観測 点または地震によらず共通な形をとる [Rautian and Khalturin (1978)]. そこでこのような時間ウィンドウで

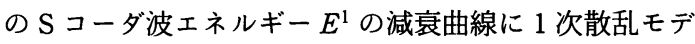
ルをあてはめて, コーダ波減衰 $\left(Q_{C}^{-1}\right)$ を推定することが 広く行われてきた (Fig. 4). $E^{1}$ はバンドパスフィルター （通常はオクターブ幅のフィルター [Tsujiura (1978)]）

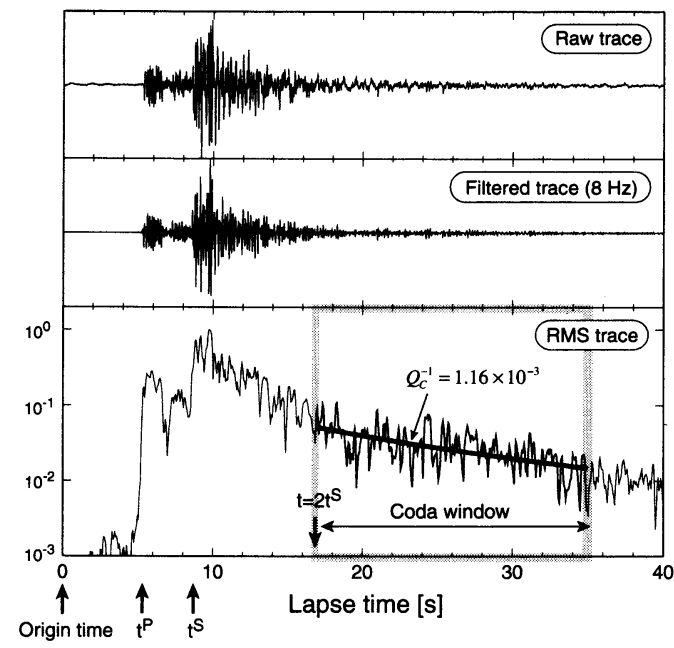

Fig. 4. An example of coda method to determine $Q_{C}^{-1}$. The traces are, from top to bottom, raw data, filtered trace with a center frequency of $8 \mathrm{~Hz}$, and rms trace. The logarithm of rms coda amplitude in the coda window is fitted to the single scattering model (bold line) to obtain $Q_{C}^{-1}$ from the slope.

を通した 2 乗平均速度振幅から求める. § 3 では $E^{1}$ を 周波数の関数として陽には示していないが, フィルター の帯域を変えて解析を行うことにより， $Q_{C}^{-1}$ を周波数の 関数として求めることができる. $Q_{C}^{-1}$ の推定は 1 観測点 のデータからであ可能であり, 解析あ簡単であることか ら，1980年代以降に世界各地において広く行われるよ うになった。

$Q_{C}^{-1}$ の測定結果のばらつきは大きいが，一般に周波数 に逆比例して小さくなる(Fig.5). 大まかに見ると, $1 \mathrm{~Hz}$ では $10^{-2}$ 程度, $20 \mathrm{~Hz}$ で $10^{-3}$ 程度の值をとる. また, 火山地域や地款浅部では大きな值をとる傾向がある. Matsumoto and Hasegawa (1989) は東北地方の火山地 域での $Q_{C}^{-1}$ が大きいことを, Kosuga (1992) は地壳浅 部の地震からの $Q_{C}^{-1}$ はより深部の地震からの $Q_{C}^{-1}$ より あ大きいことをそれぞれ示した. $Q_{C}^{-1}$ の周波数依存性 は, $f$ を周波数として $1 \mathrm{~Hz}$ 以上の帯域で

$$
Q_{C}^{-1}=Q_{0}^{-1} f^{-n}
$$

のように書ける. $Q_{0}^{-1}$ は $1 \mathrm{~Hz}$ での $Q_{C}^{-1}$ である. $n$ は $0.5 \sim 1.0$ 程度の值をとる. 多くの場合の $Q_{C}^{-1}$ の測定は, $1 \sim 30 \mathrm{~Hz}$ の周波数帯域で行われてきた.これよりあ特 に高周波領域での測定例としては，南アフリカの金鉱 山における数百 $\mathrm{Hz}$ での測定 [Cichowicz and Green (1989)] や， カナダの 3 カ所の鉱山における $150 \mathrm{~Hz} \sim 3$ $\mathrm{kHz}$ での測定 [Feustel (1998)]などがある. 


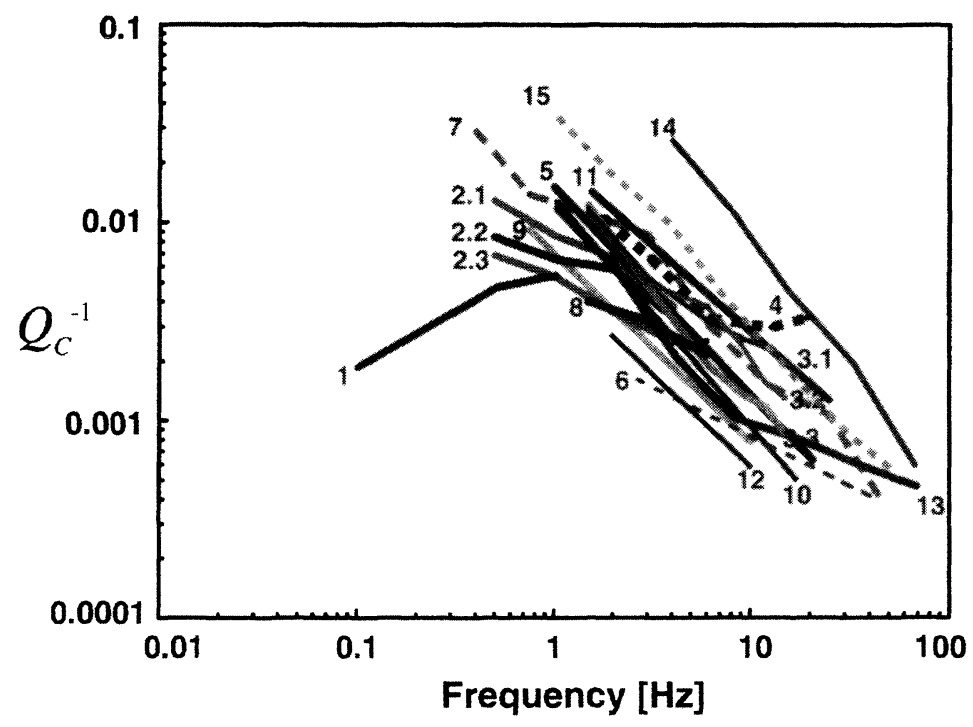

Fig. 5. $Q_{C}^{-1}$ versus frequency for various regions in the world [after Sato and Fehler (1998) with permission from Springer-Verlag]. Numerals represent different regions.

\section{$4.3 Q_{C}^{-1}$ と地域のテクトニクス}

散乱モデルに基づくと， $Q_{C}^{-1}$ は震源と観測点を焦点と する棈円体（散乱楕円体）内から散乱されてきた波によ る振幅の時間減衰率を表すので， $Q_{C}^{-1}$ は散乱楕円体内で の平均的なコーダ波減衰を表すと考えられている，その 考えを発展させて， $Q_{C}^{-1}$ の空間分布を卜モグラフィ一的 に求めた研究もある. Singh and Herrmann (1983) は, アメリカ合衆国内での $Q_{C}$ の等値線を描き, 最も古い岩 石が露出している大陸中央部での $Q_{C}^{-1}$ が最む小さく, 西部では大きいことを示した. Baqer and Mitchell (1998) はアメリカでの広帯域ディジタル地震計ネット ワークの記録から Lg 波のコーダ $Q$ を求め, backprojection 法で $Q_{0}$ と $n$ の空間分布を求めた. $Q_{0}$ の分布 傾向は Singh and Herrmann (1983) の結果と同様であ る. Jin and Aki (1988) は中国大陸での $Q_{C}^{-1}$ を求めて歴 史地震の空間分布と比較し, 歷史地震は $Q_{C}^{-1}$ の大きな 領域で発生していることを見いだした.これらの観測結 果は, テクトニックに安定な領域では $Q_{C}^{-1}$ が小さく, 活 動的な領域では大きいことを示す.

$Q_{C}^{-1}$ とテクトニクスの相関については, Jin and Aki (1989, 1991)のように, 散乱に寄与するクラック密度が テクトニックな活動度と関係するためと考えるのが一般 的であろう. 最近，これとは異なる解釈が Mitchell ら によってなされている. Mitchell et al. (1997) および Mitchell and Cong (1998) は, $Q_{0}$ はその地域における 最新のテクトニックなイベントまたは造山運動からの経 過時間に比例して増加するように見えることを示した。 彼らはそれを，地殼内の水が交代変成作用によって時間

\section{とともに失われることによる内部減衰の減少に起因する と解釈した。 \\ $Q_{C}^{-1}$ について, より微細な空間分布を求めた例むあ} る. Matsumoto and Hasegawa (1989) は東北地方での $Q_{C}^{-1}$ の空間分布を求め, 火山地域や日本海側の低速度領 域での $Q_{C}^{-1}$ が大きいことを示した. O’Doherty et al. (1997) はカリフォルニアの Long Valley カルデラ地域 での $Q_{C}^{-1}$ から $\mathrm{S}$ 波の減衰構造を空間スタッキング法で 求め, カルデラ内に異常減衰域が存在することを報告し た.

\section{4 経過時間への依存性}

Rautian and Khalturin (1978) は広い経過時間レン ジでのコーダ波の振幅減衰は, 単一の $Q_{C}^{-1}$ で説明する ことができないことを指摘した．震源時からの経過時間 の関数として $Q_{C}^{-1}$ を求めると, 経過時間とともに $Q_{C}^{-1}$ が減少する現象（経過時間依存性）はHindu-Kush [Roecker et al. (1982)]，フランス [Gagnepain-Beyneix (1987)], 南ノルウェー [Kvamme and Havskov (1989)], ユーゴスラビア [Herak (1991)], 南極 [Akamatsu (1991)], 長野県西部 [Kosuga (1992)] などで報告されて おり，一般的な傾向といえる.

散乱強度と減衰が空間的に一様であれば, $Q_{C}^{-1}$ は経過 時間には依存しない， $Q_{C}^{-1}$ の経過時間依存性を観測した 研究者の多くは, 経過時間の大きな時間ウィンドウの コーダ波はより減衰の小さい領域を通ってきたと解釈し た。 また, $Q_{C}^{-1}$ は $\mathrm{S}$ 波の内部減衰 $\left(Q_{S}^{-1}\right)$ に近い值をとる という観測事実 [Aki (1980)] から， $Q_{C}^{-1}$ は $Q_{S}^{-1}$ を表 すと解釈して, Gagnepain-Beyneix (1987), Kosuga 
(1992), Kanao (1997) は $Q_{C}^{-1}$ の経過時間依存性から $Q_{S}^{-1}$ の深さ分布を推定した. Del Pezzo (1995) は $Q_{S}^{-1}$ を 深さの多項式として近似すると震源距離（経過時間に比 例）の多項式として表されることに注目し, 経過時間依 存性から多項式の係数を決定し， $Q_{S}^{-1}$ の深さ依存性へと 換算した. 一方, Gusev (1995) は $g_{0}$ が深さに逆比例す る構造を考えると経過時間依存性が説明できるとした。 Hoshiba（1994）は散乱係数之内部減衰が深さ依存性を あつ場合について，コーダ波エネルギーの時間変化をモ ンテカルロ法でシミュレーションし， $Q_{C}^{-1}$ の経過時間依 存性を再現した。このように種々の試みはあるが, $Q_{C}^{-1}$ の経過時間依存性が何を表し, それからどのような構造 が推定されるのかはまだ十分には解明されていない．

\section{$4.5 Q_{C}^{-1}$ とは何か}

観測される $\mathrm{S}$ 波の全減衰 $\left(Q_{t}^{-1}\right)$ には, 内部減衰 $\left(Q_{S}^{-1}\right)$ 之散乱减衰 $\left(Q_{S c}^{-1}\right)$ が寄与する $\left(Q_{t}^{-1}=Q_{S c}^{-1}+Q_{S}^{-1}\right)$. コーダ 波減衰を表す $Q_{C}^{-1}$ は散乱減衰之内部減衰のどちらを表 しているのだろうか? エネルギーフラックス・モデル では内部減衰と散乱減衰を分離した形で取り込んでいる が, $Q_{C}^{-1}$ を内部減衰と散乱減衰の単純な組み合わせで表 すことはできない [Frankel and Wennerberg (1987)]. 観測からは， $Q_{C}^{-1}$ が $Q_{S}^{-1}$ に近い值をとる場合 [Fehler et al. (1992), Hoshiba (1993)] と， $Q_{S}^{-1}$ と $Q_{t}^{-1}$ の中間的な 值をとる場合 [Mayeda et al. (1992), Jin et al. (1994)] 之 が報告されている. 周波数によって異なる例ああり, 南 スペインとアナトリアでの $4 \sim 8 \mathrm{~Hz}$ 帯では $Q_{S}^{-1}$ に近い 值をとり， $8 \mathrm{~Hz}$ 以上では $Q_{t}^{-1}$ に近い值をとる [Akinci et al. (1995)]. このように, $Q_{C}^{-1}$ とは何かに対する十分 な解答はまだ得られていない [河原 (1997)].

これに対して最近，層構造を考えて解釈しょうという 試みがある. Yomogida et al. (1997) は 2 層モデルで $\mathrm{SH}$ 波の伝播をシミュレーションし， $Q_{C}^{-1}$ を測定した。 その結果, 下層で散乱された波がコーダ波のエンベロー プを形成し，時間減衰率は下層の内部減衰で規定される ことがわかった。このことから， $Q_{C}^{-1}$ は下部地殼の内部 減衰を反映すると解釈した. Margerin et al. (1998) は地 殼とマントルの 2 層構造で地震波速度と散乱強度が異 なる場合 (Fig. 6) について, 輻射伝達方程式をモンテカ ルロ法を用いて解いた。 内部減衰がない場合のコーダ波 振幅の減衰は，1 次散乱モデルによる解と同様に

$$
t^{-1} \exp \left(-2 \pi f t / Q_{C}^{*}\right)
$$

之書ける. $Q_{C}^{*-1}$ はモホでの反射係数, 地款中での平均自 由行程（散乱係数の逆数）および周波数の関数となり, 地殸中にトラップされた散乱波のエネルギーがマントル 中に逸散していく割合を表す．現実的なパラメー夕を与 えて計算したところ， $Q_{C}^{*-1}$ は $Q_{C}^{-1}$ とほとんど同じ值を

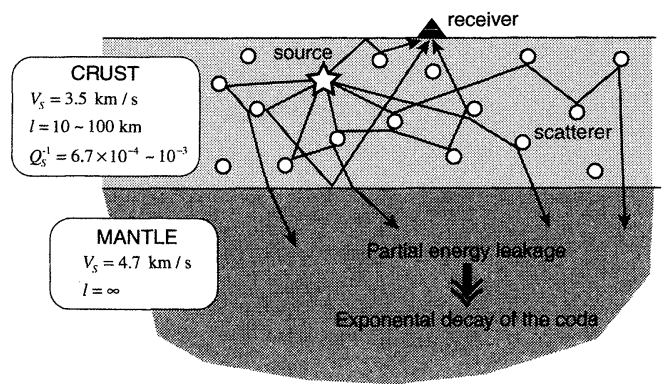

Fig. 6. Geometry and physical parameters of the model by Margerin et al. (1999). Waves emitted from the source (asterisk) are multiple scattered by scatterers (circles) in the crust. Some scattered waves arrive at the receiver (triangle) and some leak to the upper mantle. After Margerin et al. (1999) with permission from Blackwell Science.

とることがわかった. Margerin et al. (1999) はこのモデ ルをメキシコの 4 観測点でのデー夕に適用し, 低周波 $(\sim 1 \mathrm{~Hz})$ ではエネルギーの逸散が $Q_{C}^{-1}$ に効くのに対し， 高周波 $(\sim 10 \mathrm{~Hz})$ ではエネルギーの逸散だけでは説明す ることができず, 内部減衰が卓越するという結果を得 た。このような解釈は興味深いが，どの地域でも地殼と マントルという単純な 2 層構造で説明できるのか, 今後 さらに検討が必要である.

\section{§5. 一様な構造では説明できないコーダ波振幅（エ ンベロープ）の特徵}

\section{1 減衰曲線のゆらき}

§ 3 で紹介した散乱モデルでは, 散乱係数と $Q_{C}^{-1}$ が空 間的に一定であることを仮定している，その場合の減衰 曲線はなめらかな形になるが, 実際の減衰曲線はゆらぎ をむっている，そのゆらぎを特徵づけたり，ゆらぎに着 目して, 一様ランダムな構造では説明できない不均質性 を解明しようという研究も行われてきた。

コーダ波中の特定の位相に注目した例としては，南関 東での地殼内地震のコーダ波エンベロープを調べた Obara and Sato (1988) や Obara (1989) の研究がある. 彼らは太平洋プレートの上面で S-S 反射した波を発見 し，さらに，反射波自身むコーダ波を伴い，振幅の時間 減衰率が S コーダ波の時間減衰率と同程度であること を見いだした. Phillips et al. (1993) は府中アレイの水 平動成分に大振幅の位相を発見し, 波の偏向や slantstack を用いた解析から，この波は関東平野と関東山地 の境界での散乱で生じた Love 波と結論づけた. Kosuga (1997) は東北地方で観測される S 波のコーダ 波には, 一定間隔で振幅が増減する現象が見られること 
があることを見いだして，この現象をコーダ波のリップ ルと名づけた.リップルの出現は震源位置には依存する が観測点の位置にはあまり依存しないことから, 太平洋 プレート内での多重反射のような, 伝播経路で生じた波 と解釈した。一方, 多数のゆらぎから地下の散乱強度の 分布を決定論的に推定した例むある. Nishigami (1991) は減衰曲線のゆらぎから散乱強度の空間分布を推定する インバージョン手法を開発した. 彼はこの手法を飛騨,

日光・白根, 北陸, カリフォルニアのサン・アンドレア ス断層周辺地域などに適用し [Nishigami (1997, 2000)], サン・アンドレアス断層では断層セグメントの 境界付近で散乱強度が強いなどの興味深い結果を得た。

Revenaugh (1995b) はコーダ波エネルギーの起源（散 乱ポテンシャル）をマッピングするキルヒホッフ・マイ グレーション法 [Revenaugh (1995a)] で, 南カリフォ ルニアの Transverse Range 下に沈み込むスラブの南 翼が強い散乱帯となっていることを示した. 散乱強度の 空間分布の推定についての詳細は, 本号の西上 (2001) を参照されたい.

\section{2 アレイ解析による散乱体の推定}

アレイ解析から地震波散乱体の分布を推定した研究は 数多くなされており, 日本における最近の解析例として は, 兵庫県南部地震の震源域周辺についての Matsumoto et al. (1998), 東北地方の脊梁山地についての松 本・他 (1999) および浅野・他 (1999) による研究などが ある. アレイ解析からの散乱体の検出については, 本号 の松本 (2001) を参照されたい.

散乱体の位置は特定できないまでも, 散乱強度の不均 質な分布を推定した例も多い. Wagner (1997) は南カリ フォルニアの Piñon Flat でのアレイ観測データから,

近地の $\mathrm{P}$ 波, $\mathrm{S}$ 波, $\mathrm{Lg}$ 波のコーダ波中でのコヒーレン トな波を生じる散乱体は, 直達波の波線に沿う限られた 領域に存在すると考えた. Obara (1997) は, 淡路島で観 測した人工地震のコーダ波エンベロープを解析し，振幅 の減衰曲線が一時的に上昇あるいは平坦になる場合があ ることを見いだした．この現象は $\mathrm{P}$ 波の強い散乱源が 20〜25 km の深さにあるとすれば説明可能である. 松 本・他 (1995) は日光周辺での 2 力所のアレイ記録を 1 次散乱理論を用いて解析し, 火山に囲まれた地域では相 関距離が $1 \mathrm{~km}$ 程度以下の不均質性が強いと解釈した.

アレイ解析ではないが, Nishimura et al. (1997) は ニューメキシコの Jamez 火山地域での人工地震記録を 1 次散乱モデルで解析し, 最も強い散乱はカルデラ中央 部の地殼浅部で生じていることを見いだした．Aki and Ferrazzini (2000) は Piton de la Fouraise 火山におい て,コーダ波エネルギーが空間的に局在化する例を報告
している.

\section{3 散乱の異方性}

散乱モデルの多くは等方的な散乱を仮定しているが, 非等方的な散乱を示唆する観測あある. Multiple LapseTime Window 解析 (MLTW 法, 4.1 参照) でのデータ のフィッティングが不十分な場合の原因の一つとして, 等方散乱を仮定していること [Akinci et al. (1995), Fehler et al. (1992), Hoshiba (1993)] と, $Q_{S c}^{-1} や Q_{S}^{-1}$ に深さ依存性があること [Hoshiba (1993)] が挙げられ ている. Dougherty et al. (1995) は北西大西洋の ODP 掘削孔周辺での地震探査記録を解析し, コーダ波エネル ギーが過去（1 億 800 万年前）の海洋底拡大の方向で大 きいことを示した，その原因として，散乱が海底下のク ラックまたは方向性のある不均質によって生じていると 解釈した. Wagner (1996) は, P 波, S 波, Lg 波のコー ダ波においてコヒーレントに前方散乱された波が引き続 き到来することは, 異方的な不均質によって前方散乱さ れた波が地款内の waveguide に閉じこめられることに より説明できるとした. 一方, 理論的な研究として, Sato (1995) は散乱の方向依存性がある場合の問題を定 式化した. 散乱の方向依存性が有限次数の球面調和関数 で書けるなら, 有限次元の連立 1 次方程式を解くことで 解が得られることを示した. 詳細は Sato and Fehler (1998) を参照されたい. Hoshiba (1995) は西日本の 3 観測点で観測された $\mathrm{S}$ 波直後のコーダ波エネルギーは 等方多重散乱モデルから期待されるよりも大きいことを 示し, モンテカルロ法によるシミュレーションから, 非 等方散乱を考えると説明可能であると述べている.

\section{§6. リソスフェアのランダム不均質樓造}

2.2 で紹介したように, ランダム不均質構造を不均 質の自己相関関数の型, 速度ゆらぎの大きさ $\varepsilon$, 相関距離 $a$ で特徴づけ, 地震波の散乱の解析からそれらを推定す る研究も数多く行われてきた. $\varepsilon や ~ a$ は前章までに扱っ てきた散乱係数 $\left(g_{0}\right.$ または $\left.g_{\pi}\right)$ と関係する. たとえば, 指数関数型の自己相関関数でモデル化される不均質構造 においては, $g_{\pi}$ は $\varepsilon^{2} / a$ に比例する [Sato and Fehler (1998), 吉本 (2001)]. 散乱解析からの $\varepsilon$ や $a$ の推定に は, 1 次散乱モデルまたはエネルギーフラックス・モデ ルを用いる場合むあるが, 媒質の不均質性を数值的に表 現して行う波動伝播のシミュレーションも用いられてき た. データとしては近地地震・遠地地震の他に, 人工地 震む用いられている.

シミュレーションに基づく研究は, Frankel and Clayton (1984) によって始められた. 彼らは, P 波速度 のゆらぎを導入して散乱を差分法で計算した. その後, 
P 波速度之密度 [Jannaud et al. (1992), Roth and Korn (1993)], $\mathrm{P}$ 波速度と $\mathrm{S}$ 波速度に相関のあるゆらぎ [Wagner and Langston (1992), Frankel and Clayton (1986)], $\mathrm{P}$ 波速度・S 波速度・密度が相関をもって変わ る場合 [Emmerich (1992)], $\mathrm{P}$ 波速度, $\mathrm{S}$ 波速度, $Q_{P}, Q_{S}$, 密度の変化に相関がある場合 [Chang and McMechan (1996)] などのように，次第に複雑な場合のシミュレー ションが行われるようになってきた。 シミュレーション に関しては, 河原 (1997) の総合報告も参照されたい.

\section{1 地款内の不均質性}

Yoshimoto et al. (1997b) は日光地域で観測した地 震波の 3 成分エンベロープ解析 [Yoshimoto et al. (1997a)] から, リソスフェアの不均質構造を推定した. 彼らは密度と地震波速度が指数関数型の自己相関関数を もつと仮定し, 地表の効果と震源からの放射特性を考慮 した解析を行い, $\varepsilon=5 \sim 8 \%, a=0.3 \sim 0.8[\mathrm{~km}]$ という 結果を得た. Rothert and Ritter (2000) は, 南ドイッの Gräfenberg アレイで観測した Hindu Kush の地震の P コーダ波から, 地殼において $\varepsilon=3 \sim 7 \%, a=0.6 \sim 4.8$ [km] と推定した. Hock et al. (2000) は深発地震の $\mathrm{P}$ コーダ波にエネルギーフラックス・モデルを適用し， ス ウェーデンからドイッにかけてのリソスフェアの不均質 性を調ベた。 バルト盾状地の地壳内では, $\varepsilon \sim 4 \%, a \sim 1$ $[\mathrm{km}]$, 北ドイッ・デンマーク海盆での地款内では $\varepsilon \sim$ $8 \%, a=5 \sim 10[\mathrm{~km}]$ を得た.

人工地震記録の解析としては以下のような例がある. Line et al. (1998a) は放物近似を用いた不均質媒質中の 波動伝播理論に基づき, バルト盾状地の深さ $15 \mathrm{~km}$ ま での上部地殼の不均質性は, $\varepsilon=1.5 \pm 0.5 \%, a=0.15$ $[\mathrm{km}]$ の指数関数型で表されるとした. Roth (1997) は走 時の自己相関関数と媒質のスローネスのゆらぎの関係を 波線理論的に求めた. スウェーデンのØland で行われ たエアガンのショットを解析し, ガウス型の自己相関関 数を仮定した場合に地款では $\varepsilon=2.2 \sim 5 \%, a=0.33 \sim$ $0.60[\mathrm{~km}]$ を得た. Line et al. (1998b) はスウェーデンの Siljan 探査データから $\varepsilon=0.7 \%, a=0.21[\mathrm{~km}]$ と推定し た. その東のボスニア湾での BABEL 探査からは, 地殻 上部 $1 \sim 2 \mathrm{~km}$ で $\varepsilon=4 \sim 6 \%, a=0.035[\mathrm{~km}]$, 上部 $6 \sim 8$ $\mathrm{km}$ で $\varepsilon=1.5 \%, a=0.14[\mathrm{~km}]$ と推定した.

以上をまとめると, 地域的な違いはあるが, $\varepsilon=1 \sim$ $8 \%, a=0.15 \sim 1.0[\mathrm{~km}]$ が得られている. また，上記パ ラメータは深さによって変わるが, 浅部でのゆらぎは地 表付近の亀裂に，それ以深では地殼構成物質の組成的 な不均質に起因するためとの解釈がある [Line et al. (1998a, 1998b)].

\section{2 上部マントルの不均質性}

上部マントルでの不均質性は, 遠地地震を用いた解析 や波動伝播のシミュレーションを基に推定されている.

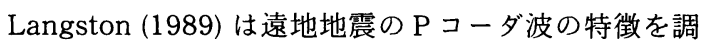
べ, 北米大陸西部と北東部での振幅と時間減衰の相違を 説明するために, 均質な層の上に不均質な層がある場合 のエネルギーフラックス・モデルを導入した。これは入 射した波が表層で散乱され，エネルギーが均質媒質へ逸 散することを考慮したものである. Korn (1990) も同様 のモデルを提唱した. Korn (1993) は拡張されたエネ ルギーフラックス・モデルを用いて, 島弧では散乱 が強く, 安定大陸では散乱が弱いことを見いだした。 Hestholm et al. (1994) は地殼と最上部マントルを表す 2 次元断面に, $\kappa=0.3$ のフォン・カルマン型で表現した ランダムな不均質性を加えて大規模なシミュレーション を行い, 実際に観測されるような複雑な地震記象を再現 できることを示した. Furumura et al. (1999) はマント ル内にフォン・カルマン型のランダムな不均質性を加え た構造において, 疑似スペクトル法により波動伝播をシ ミュレーションした. 彼らは不均質性の効果として, 実 体波については走時異常と波形の変化, レイリー波につ いては位相のずれが生じることを示した。 また，不均質 の異方性が大きくなるほよ゙影響が生じる領域は広く, 異 常の振幅も大きくなることもわかった.

不均質性を定量的に推定した例としては以下のような 研究がある. Flatté and Wu (1988) はノルウェーの NORSAR アレイ下のリソスフェアの不均質性につい て，2種類のスペクトル構造がオーバーラップした不均 質構造を提唱している. Ritter et al. (1998) はフランス の Massif Central で観測された遠地地震の P コーダ波 に Shapiro and Kneib (1993) および Shapiro et al. (1996) の理論を適用し, 同地域のリソスフェアは厚さ $70 \mathrm{~km}, \varepsilon=3 \sim 7 \%, a=1 \sim 16[\mathrm{~km}]$ で特徴づけられると した. Shapiro らの理論は, 不均質の存在によりコヒー レントな波頭のエネルギーがインコヒーレントな部分に 組み入れられる割合を $\varepsilon$ を使って表したあのである. Hock et al. (2000) は深発地震の P コーダ波にエネル ギーフラックス・モデルを適用し, 北ドイッ〜デンマー ク海盆下のリソスフェアでは $\varepsilon=6 \sim 8 \%, a=10 \sim 20$ [km]の值を得た. Mallick and Frazer (1990) は海洋り ソスフェアを伝わる波のシミュレーションから, $\varepsilon=2 \%$, $a=5[\mathrm{~km}]$ と推定した.

速度構造のゆらぎの波長が地震波の波長に比べて大き い場合, 回折効果により S 波主要動のパルス幅の増大と 最大振幅の着信の遅れが生じる. Sato (1989) はこれを 観測から明らかにし，放物近似に基づくモデルを提唱し 
た. その後 Scherbaum and Sato (1991) は, 上記モデル からインバージョンによって $\varepsilon^{2} / a$ を推定した. ただし, このモデルからでは二つのパラメータの分離はできな い. このようなエンベロープ解析の詳細は本号の小原 (2001) を参照されたい.

上部マントルでの結果をまとめると, $\varepsilon=2 \sim 8 \%, a=$ $1 \sim 20[\mathrm{~km}]$ ということになる. 地殼内と比較すると, 速 度ゆらぎの大きさはそれほど変わらないが, 相関距離が 1 桁大きいのが特徴である. 広角反射法のデー夕も, 下

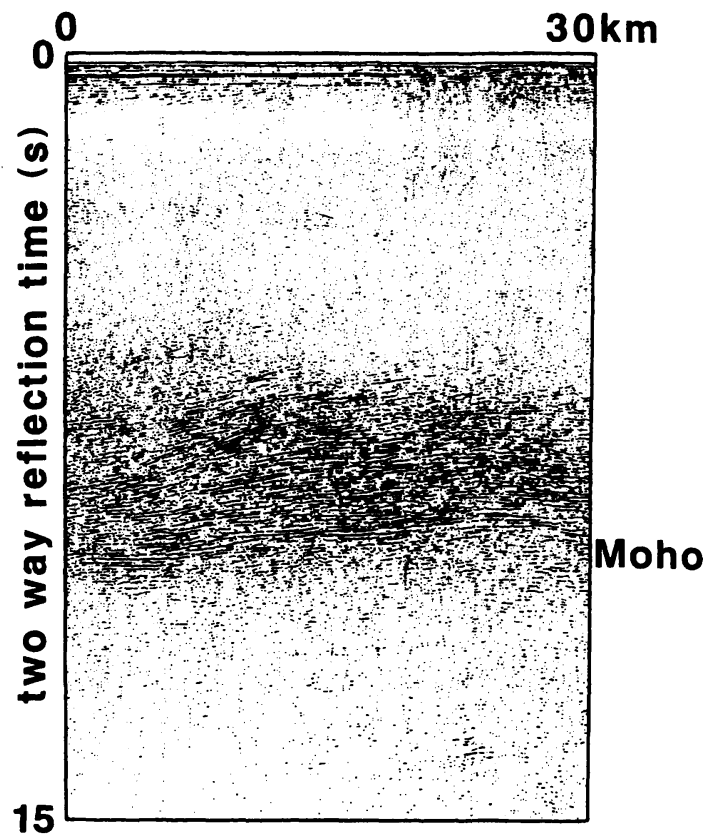

Fig. 7. Seismic reflection profile over an area of continental crust showing a highly reflective lower crust and relatively transparent upper crust and mantle [after Warner (1990) with permission from Elsevier Science].
部地殼と上部マントルではゆらぎのスケールが顕著に異 なることを示している [Enderle et al. (1997)].

\section{3 異方的な不均兵性}

Hestholm et al. (1994) はノルウェーの NORESS お よび ARCESS アレイで記録した近地地震波の解析を行 い, リソスフェアの不均質性は等方的ではないことを示 した. 地質学的データからも, 地款物質の相関距離は水 平方向が鉛直方向より屯長いことの直接的な証拠が得ら れている [Holliger and Levander (1992)]. Dolan et al. (1998) は近接して掘削された 9 本のボアホール（深さ 1000 1500 m) での速度検層データから, 水平方向の 相関距離が鉛直方向に比べて 4 倍長いことを示した.こ のように, リソスフェア内では水平方向と鉛直方向の相 関距離が異なる, 異方的な不均質性が存在することも特 徴である.

それでは，このような異方的な不均質性はどのような 構造に起因するのだろうか? 反射法探查では, 下部地 殼は無数の水平に近い反射面がランダムに分布している ことで特徴づけられ (Fig. 7), 反射的な層の下端はモホ に一致する [Mooney and Brocher (1987)]. このよう に, 明瞭な速度境界であるモホの上に高速度層と低速度 層が互層を形成しているというのが, 反射法地震探査記 録から得られるイメージである (Fig. 8). このような互 層構造が Lgコーダ波の継続時間を増加させることが, Campillo and Paul (1992) のシミュレーションによって 示されている.

一方，垂直入射に対してマントルは「透明」であると 考えられてきたが，このイメージを再考させるような データも得られている. ロシアをほぼ東西に横断する Peaceful Nuclear Explosion (PNE) において, 数千 km 以上も伝播する高周波 Pn が観測された [Ryberg et al. (1995), Fig. 9]. この波の卓越周波数は $5 \sim 10 \mathrm{~Hz}$ で, 継

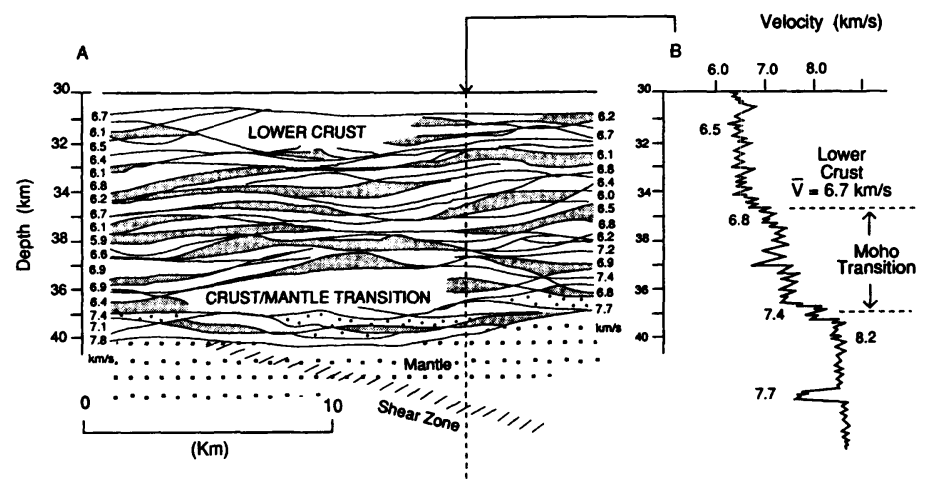

Fig. 8. Model for the lower crust and Moho that consists of lamella with high- and low-velocity [after Mooney and Meissner (1992) with permission from Elsevier Science]. 


\section{QUARTZ, Shotpoint: 323, recorded from south to north}

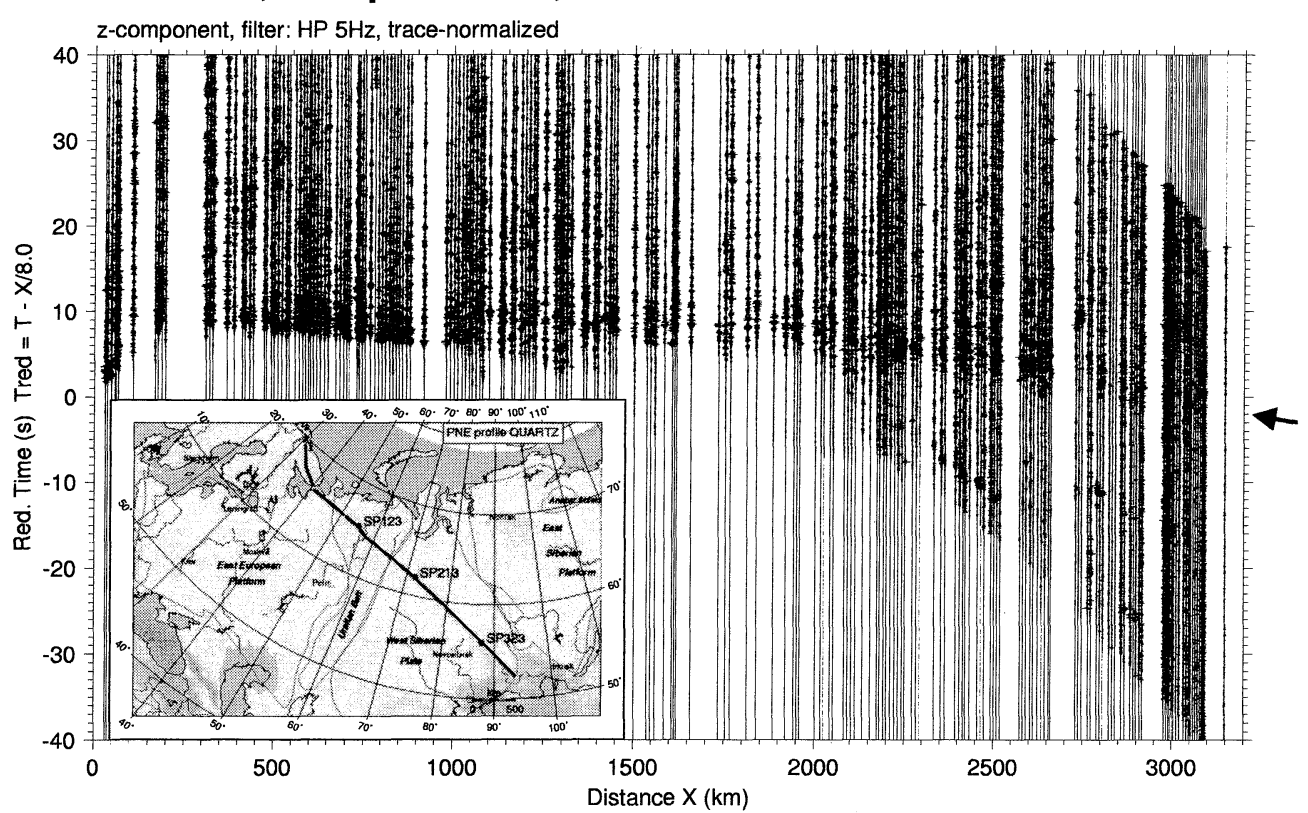

Fig. 9. High pass filtered (cut off frequency of $5 \mathrm{~Hz}$ ) vertical component time-distance record section on profile QUARTZ shown in the inset. The traces are normalized to the maximum of each trace. The strong wave band marked by an arrow is the high-frequency teleseismic Pn. After Ryberg et al. (2000) with permission from Blackwell Science.

続時間の長いインコヒーレントなコーダ波を伴うことが 特徵である.この波の成因を巡って波動伝播のシミュ レーションを基に様々な検討がなされている $[R y b e r g$ and Wenzel (1999), Ryberg et al. (2000), Tittgemeyer et al. (1996, 1999)] が，最上部マントルにあランダムな 不均質構造を考える必要があるという点が共通してい る. シミュレーションの結果, 速度ゆらぎは多重散乱を 起こすほど十分強く, 水平方向の相関距離が鉛直方向の それより 1 桁以上大きい場合に限って, 高周波 Pn が見 られることがわかった. Tittgemeyer et al. (1996, 2000) は Reflectivity 法による波形合成を行い，この Pn は上部マントルに $\pm 4 \%$ のランダムな不均質を重称 合わせると説明可能であることを示した. Ryberg and Wenzel (1999) は理論波形のコーダ $Q$ と観測された コーダ $Q$ を比較し, 層の厚さ・速度ゆらぎ $\varepsilon$ ・相関距離 $a$ を推定した. その結果, 厚さは $75 \mathrm{~km}$, 低速度と高速 度の互層の厚さが $2 \mathrm{~km}, \varepsilon=5 \%$ とすると説明可能であ るとした. Ryberg et al. (2000) は 2 次元差分法による 波動場のシミュレーションから, 高周波 Pn が再現され る条件として, 不均質層の厚さが $100 \sim 150 \mathrm{~km}$, 横方 向・鉛直方向の相関距離がそれぞれ $20 \mathrm{~km}$ と $0.5 \mathrm{~km}$, $\varepsilon \approx 2 \%$ という值を得た。ここで紹介したのはPNEの例 だけであるが, 遠地 Pn はしばしば見られる [Ryberg et al. (2000)]ことから，他の大陸においても同様な不均質 が存在すると考えるのが自然であろう.

\section{4 地款・マントル構造のイメージ}

散乱波を用いた研究から, 地殼・上部マントル・モホ の構造について, 従来とは異なるイメージも得られるよ うになってきた. Gibson and Levander (1988) はラン ダムな速度ゆらぎをおいて地震波をシミュレートし，こ れに通常の CMP スタックを行うと見かけ上の不連続的 な水平構造が現れることを示した. Levander and Holliger (1992) は同様なシミュレーションから，反射法探 查で実際に見られるような不連続な反射だけではなく, 広角反射波む生じることを示した。ささらに Levander et al. (1994b) は，2.2 で述べた Lewisian 片麻岩体のモデ ルを上部地殼に, Ivrea 岩体のモデルを下部地殼に採用 したモデルを構成し，実際の反射法記録に見られる特徵 を視覚的に良く再現する CMP 重合記録を得た。このよ うに，Fig. 8 のような互層構造とはやや異なるランダム な不均質性を地款内に考えることによっても，現実的な 理論反射法探查記象がつくれることがわかった，上部、 ントルについては，高周波 Pnを説明するために，4\% 程度の異方的なランダム不均質構造を加えたモデルが提 案された [Ryberg et al. (2000)]ことを述べた.

Figs. 10,11には最近考えられている地款・マントル 

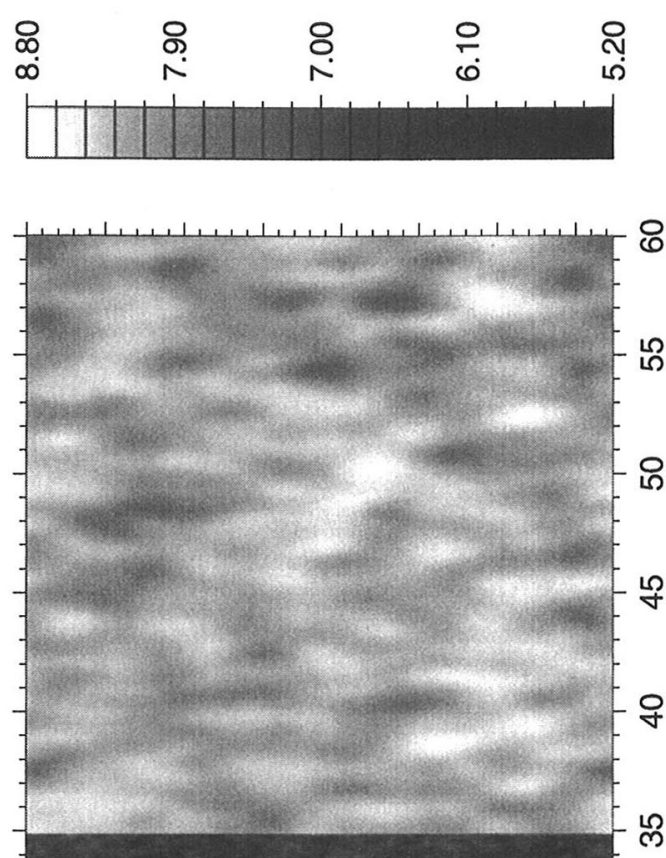

8

吕

요

웅

우

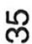

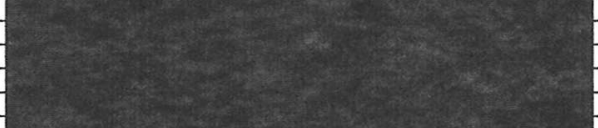

요롤

ผ

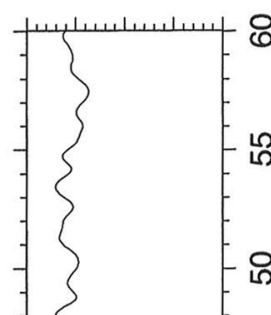

过

空

동

5.

㲾

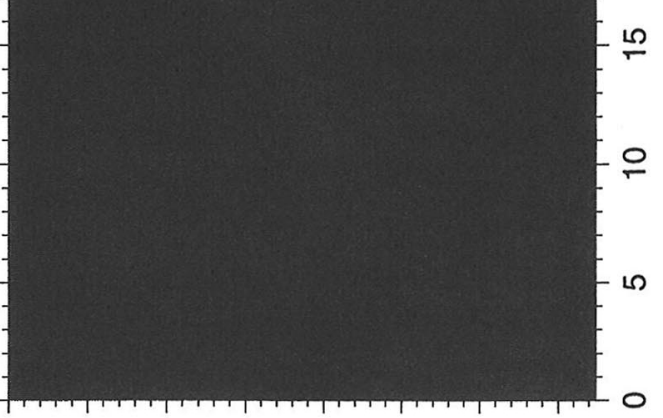

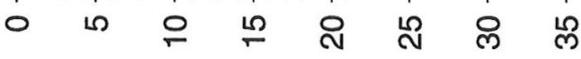
[uy] əsఘం

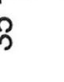




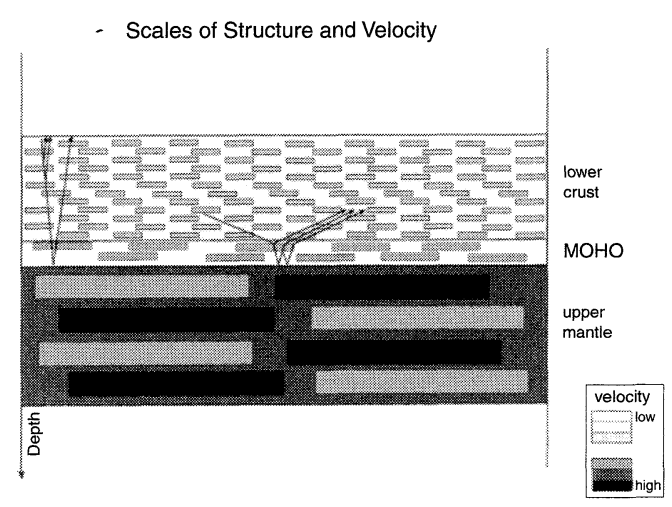

Fig. 11. Conceptional diagram indicating the inhomogeneous structure in the lower crust, upper mantle, and Moho. The three layers are characterized by anisotropic random inhomogeneities with different scale length and velocity variance (gray scale). The response of Moho to the incident wave depends on the incident angle. After Enderle et al. (1997) with permission from Elsevier Science.

構造モデルの例を示す。地殼・マントルとあランダムな 不均質性を有するが, 不均質の相関距離はマントル内の 方が大きい. また, 水平方向の相関距離が鉛直方向の相 関距離よりも大きいことも特徴である. 地殼とマントル の境界を形成するモホは, 従来は薄い速度不連続面と考 えられてきたが，その内部構造も注目されるようになっ た. Enderle et al. (1997) は, モホは地殼物質とマントル 物質が混合した層から形成され, 高周波 Pn の wave guide として働くと考えた (Fig. 11).このような地殼・ マントル・モホの構造は, 反射法地震断面からイメージ される構造 (Fig. 8) と大きく異なるものではないが, 両 者のどちらが真の構造に近いかは, 他地域のデー夕も加 えて今後さらに検討する必要がある。また，これまでに 紹介したのは大陸での研究であるが, 島弧の地殼・マン トルについての解明を進めることは, 島弧の形成史の解 明にあつながる重要な課題である.

\section{§ 7. まとめと今後の課題}

本論ではコーダ波から推定される不均質構造を概観し てきた。推定されるパラメータは, 現象論的なパラメー 夕としての散乱係数 $g_{0}$ とコーダ波減衰 $Q_{C}^{-1}$, または, 波 動論的なパラメータとしての地震波速度のゆらぎ $と$ 相 関距離 $a$ である. $g_{0}$ は $\varepsilon$ や $a$ 之関係する量である. その 結果を，特に 1990 年代に行われた研究結果を中心にま とめると, 以下のようになる.

(1) 検層データや地質データが示す不均質性のパ
ワースペクトルは, 波数のべき乗に比例することが多 い. これは $\kappa=0.1 \sim 0.3$ のフォ・カルマン型の自己相 関関数で表現できる。また，鉛直方向の相関距離が水平 方向よりも短く, 異方的な構造となっていることも明ら かになった。

（2）コーダ波減衰を表す $Q_{C}^{-1}$ とその経過時間依存性 の観測が数多く行われた. また， $Q_{C}^{-1}$ と地域のテクト二 クスとの相関が明らかになった. しかし， $Q_{C}^{-1}$ が物理的 に何を反映しているのかは，いまだにはっきりしていな い. これに対して, 層構造を考えて解釈しょうという試 みがなされている。

(3) $\varepsilon$ と $a$ を推定した結果をまとめると, 地殻内につ いては $\varepsilon=1 \sim 8 \%, a=0.15 \sim 1.0[\mathrm{~km}]$ であり, 上部マン トルでは $\varepsilon=2 \sim 8 \%, a=1 \sim 20[\mathrm{~km}]$ である．速度ゆら ぎの大きさはあまり変わらないが, 上部マントル内での 相関距離が 1 桁大きいことが特徵である．また，検層 データと同様に, 鉛直方向の相関距離は水平方向よりも 短い.

（4）反射法探查での垂直入射に対してマントルは「透 明」と見なされてきた。 しかし，大陸を伝播する高周波 Pn を説明するためには, 最上部マントルでの速度ゆら ぎは多重散乱を起こすほど強く $(\varepsilon \sim 4 \%)$, 水平方向の相 関距離が鉛直方向のそれより 1 桁以上大きいことが必 要であることがわかった。

このように，コーダ波の解析を通して地球内部の確率 論的構造のイメージは少しずつ明らかになってきた. し かし, 今後解明すべき課題む多く残されているので, 最 後にそれらを挙げておこう。

(1) $Q_{C}^{-1}$ が内部減衰 $\left(Q_{S}^{-1}\right)$ と散乱減衰 $\left(Q_{S c}^{-1}\right)$ のどちら を反映するのか, $Q_{C}^{-1}$ の経過時間依存性には散乱係数と 内部減衰の深さ依存性のどちらが影響するのかなどはま だ解明されていない， $Q_{C}^{-1}$ がそもそも，コーダ波振幅が 時間に対して指数関数的に減衰することを表すために便 宜的に導入されたパラメータであるがために，その物理 的意味の解釈に苦慮している面がある.むしろ, 物理的 内容が明確なパラメータでコーダ波減衰を記述すべきか 屯しれない. 層構造モデルによるアプローチはこのよう な試みで興味深いが, どの地域でもそれによって説明で きるのか, さらに検討する必要がある.

（2）下部地壳にランダムな速度ゆらぎをもつ地震波 速度構造を考えると, 実際の反射法記録に見られる特徴 を視覚的に良く再現することがわかってきた，下部地殼 には水平に近い高速度・低速度の互層があるのか, ラン ダムな速度ゆらぎを考えるだけで良いのかを明らかにす る必要がある.

(3) モホや上部マントルの不均質構造について屯解 
析地域を増やして検討する必要がある．特に，これまで の研究は主として大陸において行われてきたので, 島弧 での研究を進めることが必要である.

(4) コーダ波を用いた解析は $\varepsilon$ と $a$ の定量的な測定 に大きく貢献してきたが，それらの值は空間平均したも のを見ている場合が多い.これは確率論的アプローチの 欠点でああるのだが, 決定論的手法とのハイブリッドな 解析手法を工夫するなどして, 空間分解能を上げる必要 がある．これは上記 (4) の解明のためにも必要である.

(5) 確率論的地下構造モデルに基づいたグリーン関 数を用い, 震源パラメー夕の推定を行うことも有望であ る.これはすでに始められているが [例えば, Nakahara et al. (1998)], より現実的な構造に対する解析手法の開 発と計算処理手法の効率化が必要である.

\section{謝 辞}

查読者の佐藤春夫氏 (東北大学) と竹中博士氏（九州 大学）からの適切なコメントは, 原稿の改善に大変有益 であった. Marc Tittgemeyer および Trond Ryberg の 両氏には, 作図にあたってディジタルデー夕を使用させ ていただいた. 本研究は, 東京大学地震研究所共同研究 プログラム (2000-B-07) の援助を受けた. 記して謝意を 表する.

\section{文献}

Abubakirov, I. R. and A. A. Gusev, 1990, Estimation of scattering properties of lithosphere of Kamchatka based on Monte-Carlo simulation of record envelope of a near earthquake, Phys. Earth Planet. Interiors, 64, 52-97.

Akamatsu, J., 1991, Coda attenuation in the LützowHolm Bay Region, east Antarctica, Phys. Earth Planet. Interiors, 67, 65-75.

Aki, K., 1969, Analysis of the seismic coda of local earthquakes as scattered waves, J. Geophys. Res., 74, 615-631.

Aki, K., 1980, Scattering and attenuation of shear waves in the lithosphere, J. Geophys. Res., 85, 64966504.

Aki, K. and B. Chouet, 1975, Origin of coda waves: source, attenuation, and scattering effects, J. Geophys. Res., 80, 3322-3342.

Aki, K. and V. Ferrazzini, 2000, Seismic monitoring and modeling of an active volcano for prediction, J. Geophys. Res., 105, 16617-16640.

Aki, K. and P. G. Richards, 1980, Quantitative Seismology. Theory and Methods, Freeman, San Francisco, 932 pp.

Aki, K. and M. Tsujiura, 1959, Correlation study of near earthquake waves, Bull. Earthq. Res. Inst., 37, 207-232.
Akincl, A., E. Del Pezzo and J. M. Ibáñez, 1995, Separation of scattering and intrinsic attenuation in southern Spain and western Anatolia (Turkey), J. Geophys. Res., 121, 337-353.

浅野陽一・海野徳仁・中村綾子・岡田知己・堀 修一 郎・河野俊夫・仁田交市・佐藤俊也・長谷川 昭・小 菅正裕・長谷見晶子, 1999, DAT アレイ地震観測に よる奥羽脊梁山地およびその周辺域における地震波散 乱体分布の推定, 地震 $2, \mathbf{5 2}, 379-394$.

Baqer, S. and B. J. Mitchell, 1998, Regional variation of $\mathrm{Lg}$ coda $Q$ in the continental United States and its relation to crustal structure and evolution, Pure Appl. Geophys., 153, 613-638.

Baskoutas, I., 1996, Dependence of coda attenuation on frequency and lapse time in central Greece, Pure Appl. Geophys., 147, 483-496.

Campillo, M. and A. Paul, 1992, Influence of the lower crustal structure on the early coda of regional seismograms, J. Geophys. Res., 97, 3405-3416.

Chang, H. and G. A. McMechan, 1996, Numerical simulation of multi-parameter seismic scattering, Bull. Seism. Soc. Am., 86, 1820-1829.

Cichowicz, A. and R. W. E. Green, 1989, Changes in the early part of the seismic coda due to localized scatterers: The estimation of $Q$ in a stope environment, Pure Appl. Geophys., 129, 497-511.

Cleary, J. R. and R. A. W. Haddon, 1972, Seismic wave scattering near the core-mantle boundary: a new interpretation of precursors to PKP, Nature, 240, 549-551.

Dainty, A. M., R. M. Duckworth and A. Tie, 1987, Attenuation and backscattering from local coda, Bull. Seism. Soc. Am., 77, 1728-1747.

Del Pezzo, E., 1995, Estimate of the Q-depth pattern from coda- $Q$ measurement, Phys. Earth Planet. Interiors, 88, 79-82.

Dolan, S. S., C. J. Bean and B. Riollet, 1998, The broadband fractal nature of heterogeneity in the upper crust from petrophysical logs, Geophys. J. Int., 132, 498-507.

Dougherty, M.E., R. J. Vincent, S. A. Swift and R. A. Stephen, 1995, Anisotropic seismic scattering in old Atlantic crust, J. Geophys. Res., 100, 1009510106.

Emmerich, H., 1992, PSV-wave propagation in a medium with local heterogeneities: a hybrid formulation and its application, Geophys. J. Int., 109, 54-64.

Enderle, U., M. Tittgemeyer, M. Itzin, C. Prodehl and K. Fuchs, 1997, Scales of structure in the lithosphere-images of processes, Tectonophysics, 275, 165-198.

Fehler, M., M. Hoshiba, H. Sato and K. Obara, 1992, Separation of scattering and attenuation for the Kanto-Tokai region, Japan, using measurements of S-wave eneregy versus hypocentral distance, Geophys. J. Int., 108, 787-800. 
Feustel, A. J., 1998, Seismic attenuation in underground mines: a comparative evaluation of methods and results, Tectonophysics, 289, 31-49.

Flatté, S. M. and R.-S. Wu, 1988, Small-scale structure in the lithosphere and asthenosphere deduced from arrival time and amplitude fluctuations at NORSAR, J. Geophys. Res., 93, 6601-6614.

Frankel, A. and R.W. Clayton, 1984, A finitedifference simulation of wave propagation in twodimensional random media, Bull. Seism. Soc. Am., 74, 2167-2186.

Frankel, A. and R. W. Clayton, 1986, Finite difference simulations of seismic scattering: Implications for the propagation of short-period seismic waves in the crust and models of crustal heterogeneity, J. Geophys. Res., 91, 6465-6489.

Frankel, A. and L. Wennerberg, 1987, Energy-flux model of seismic coda: separation of scattering and intrinsic attenuation, Bull. Seism. Soc. Am., 77, 1223-1251.

Furumura, M., B. L. N. Kennett and T. Furumura, 1999, Seismic wavefield calculation for laterally heterogeneous earth models-II. The influence of upper mantle heterogeneity, Geophys. J. Int., 139, 623-644.

Gagnepain-Beyneix, J., 1987, Evidence of spatial variations of attenuation in the western Pyrenean range, Geophys. J. Roy. Astr. Soc., 89, 681-704.

Gao, L. S., L. C. Lee, N. N. Biswas and K. Aki, 1983, Comparison of the effects between single and multiple scattering on coda waves for local earthquakes, Bull. Seism. Soc. Am., 73, 377-389.

Gibson, B. S. and A. R. Levander, 1988, Modeling and processing of scattered waves in seismic reflection surveys, Geophysics, 53, 466-478.

Gusev, A. A., 1995, Vertical profile of turbidity and coda $Q$, Geophys. J. Int., 123, 665-672.

Gusev, A. A. and I. R. Abubakirov, 1987, Monte-Carlo simulation of record envelope of a near earthquake, Phys. Earth Planet. Interiors, 49, 30-36.

Gusev, A. A. and I. R. Abubakirov, 1999, Vertical profile of effective turbidity reconstructed from broadening of incoherent body-wave pulses-II. Application to Kamchatka data, Geophys. J. Int., 136, 309-323.

Herak, M., 1991, Lapse-time dependent $Q_{C}$-spectra observed in the Dinarides region (Yugoslavia), Phys. Earth Planet. Interiors, 67, 303-312.

Herraiz, M. and A. F. Espinosa, 1987, Coda waves: a review, Pure Appl. Geophys., 125, 499-577.

Hestholm, S. O., E. S. Husebye and B. O. Rudd, 1994, Seismic wave propagation in complex crust-upper mantle media using 2-D finite-difference synthetics, Geophys. J. Int., 118, 643-670.

Hock, S., M. Korn and T. T. W. Group, 2000, Random heterogeneity of the lithosphere across the TransEuropean Suture Zone, Geophys. J. Int., 141, 57-70.
Holliger, K., 1996, Upper-crustal seismic velocity heterogeneity as derived from a variety of $\mathrm{P}$-wave sonic logs, Geophys. J. Int., 125, 813-829.

Holliger, K. and A. R. Levander, 1992, A stochastic view of lower crustal fabric based on evidence from the Ivrea zone, Geophys. Res. Lett., 19, 11531156.

Holliger, K. and A. Levander, 1994, Seismic structure of gneissic/granitic upper crust: geological and petrophysical evidence from the Strona-Ceneri Zone (northern Italy) and implications for crustal seismic exploration, Geophys. J. Int., 119, 497-510.

Hoshiba, M., 1991, Simulation of multiple-scattered coda wave excitation based on the energy conservation law, Phys. Earth Planet. Interiors, 67, 123136.

Hoshiba, M., 1993, Separation of scattering attenuation and intrinsic absorption in Japan using the multiple lapse time window analysis of full seismogram envelope, J. Geophys. Res., 98, 15809-15824.

Hoshiba, M., 1994, Simulation of coda wave envelope in depth dependent scattering and absorption structure, Geophys. Res. Lett., 21, 2853-2856.

Hoshiba, M., 1995, Estimation of nonisotropic scattering in western Japan using coda wave envelopes: Application of a multiple nonisotropic scattering model, J. Geophys. Res., 100, 645-657.

干場充之, 2001, 輻射伝達理論およびモンテカルロシ ミュレーションによるコーダエンベロープの記述, 地 震 2, 54, 109-125.

Jannaud, L. R., P. M. Adler and C. G. Jacquin, 1992, Wave propagation in random anisotropic media, $\mathrm{J}$. Geophys. Res., 97, 15277-15289.

Jin, A. and K. Aki, 1988, Spatial and temporal correlation between coda $Q$ and seismicity in China, Bull. Seism. Soc. Am., 78, 741-769.

Jin, A. and K. Aki, 1989, Spatial and temporal correlation between coda $Q^{-1}$ and seismicity and its physical mechanism, J. Geophys. Res., 94, 1404114059.

Jin, A. and K. Aki, 1991, Observational and Physical Bases for the coda $Q^{-1}$ precursor, in "Evaluation of Proposed Earthquake Precursors", ed. by M. Wyss, American Geophysical Union, Washington, D. C., 33-46.

Jin, A., K. Mayeda, D. Adams and K. Aki, 1994, Separation of intrinsic and scattering attenuation in southern California using TERRAscope data, J. Geophys. Res., 99, 17835-17848.

Kanao, M., 1997, Variations in the crustal structure of the Lüzow-Holm Bay region, East Antarctica using shear wave velocity, Tectonophysics, 270, 43-72.

河原 純, 1997, ランダム媒質中の波動伝播の数値 シ ミュレーション, 地震 2, 50, 135-156.

Kneib, G., 1995, The statistical nature of the upper continental crystalline crust derived from in situ 
seismic measurements, Geophys. J. Int., 122, 594616.

Kopnichev, Y. F., 1975, A model of generation of the tail of the seismogram, Doklady Akad. Nauk SSSR (English trans.), 222, 333-335.

Korn, M., 1990, A modified eneregy flux model for lithospheric scattering of teleseismic body waves, Geophys. J. Int., 102, 165-175.

Korn, M., 1993, Determination of site-dependent scattering $Q$ from $\mathrm{P}$-wave coda analysis with an energy-flux model, Geophys. J. Int., 113, 54-72.

Kosuga, M., 1992, Dependence of coda $Q$ on frequency and lapse time in the western Nagano region, central Japan, J. Phys. Earth, 40, 421-445.

Kosuga, M., 1997, Periodic ripple of coda envelope observed in northeastern Japan, Phys. Earth Planet. Interiors, 104, 91-108.

Kvamme, L. B. and J. Havskov, 1989, $Q$ in southern Norway, Bull. Seism. Soc. Am., 79, 1575-1588.

Langston, C. A., 1989, Scattering of teleseismic body waves under Pasadena, California, J. Geophys. Res., 94, 1935-1951.

Leonardi, S. and H.-J. Kümpel, 1998, Variability of geophysical log data and the signature of crustal heterogeneities at the KTB, Geophys. J. Int., 135, 964-974.

Levander, A. R. and K. Holliger, 1992, Small-scale heterogeneity and large-scale velocity structure of the continental crust, J. Geophys. Res., 97, 87978804.

Levander, A., R. W. England, S. K. Smith, R. W. Hobbs, J. A. Goff and K. Holliger, 1994a, Stochastic characterization and seismic response of upper and middle crustal rocks based on the Lewisian gneiss complex, Scotland, Geophys. J. Int., 119, 243-259.

Levander, A., R. W. Hobbs, S. K. Smith, R. W. England, D. B. Snyder and K. Holliger, 1994b, The crust as a heterogeneous "optical" medium, or "crocodiles in the mist", Tectonophysics, 232, 281-297.

Line, C. E. R., R. W. Hobbs, J. A. Hudson and D. B. Snyder, 1998a, Statistical inversion of controlledsource seismic data using parabolic wave scattering theory, Geophys. J. Int., 132, 61-78.

Line, C. E. R., R. W. Hobbs and D. B. Snyder, 1998b, Estimates of upper-crustal heterogeneity in the Baltic Shield from seismic scattering and borehole logs, Tectonophysics, 286, 171-183.

Mallick, S. and L. N. Frazer, 1990, Po/So synthetics for a variety of oceanic models and their implications for the structure of the oceanic lithosphere, Geophys. J. Int., 100, 235-253.

Margerin, L., M. Campillo and B. V. Tiggelen, 1998, Radiative transfer and diffusion of waves in a layered medium: new insight into coda $Q$, Geophys. J. Int., 134, 596-612.

Margerin, L., M. Campillo, N. M. Shapiro and B. V. Tiggelen, 1999, Residence time of diffuse waves in the crust as a physical interpretation of $\operatorname{coda} Q$ : application to seismograms recorded in Mexico, Geophys. J. Int., 138, 343-352.

Matsumoto, S., 1995, Characteristics of coda waves and inhomogeneity of the Earth, J. Phys. Earth, 43, 279-299.

松本 聡, 2001 , 地震計アレイ観測に基づく不均質構造 の推定, 地震 2, 54, 193-201.

Matsumoto, S. and A. Hasegawa, 1989, Twodimensional coda $\mathrm{Q}$ structure beneath Tohoku, NE Japan, Geophys. J. Int., 99, 101-108.

松本 聡 - 津村紀子 - 開原貴美 - 岡田知己 - 堀内茂木 長谷川 昭・伊東明彦, 1995, 日光周辺域におけるア レイ観测から得られた P コーダ波の性質と不均質構 造, 地震 2, 48, 387-399.

Matsumoto, S., K. Obara and A. Hasegawa, 1998, Imaging $\mathrm{P}$-wave scatterer distribution in the focal area of the 1995 M7.2 Hygo-ken Nanbu (Kobe) Earthquake, Geophys. Res. Lett., 25, 1439-1442.

松本 聡・小原一成・吉本和生・斎藤竜彦・長谷川 昭・伊東明彦, 1999, 短スパンアレイ観測による奥羽 春梁山地周辺の地殻不均質構造のイメージング, 地震 2, 52, 283-297.

Mayeda, K., S. Koyanagi, M. Hoshiba, K. Aki and Y. Zeng, 1992, A comparative study of scattering, intrinsic, and coda $Q^{-1}$ for Hawaii, Long Valley, and central California between 1.5 and $15.0 \mathrm{~Hz}, \mathrm{~J}$. Geophys. Res., 97, 6643-6659.

Mitchell, B. J. and L. Cong, 1998, Lg coda $Q$ and its relation to the structure and evolution of continents: A global perspective, Pure Appl. Geophys., 153, 655-663.

Mitchell, B. J., Y. Pan, J. Xie and L. Cong, 1997, Lg coda $Q$ variation across Eurasia and its relation to crustal evolution, J. Geophys. Res., 102, 2276722779.

Mooney, W. D. and T. M. Brocher, 1987, Coincident seismic reflection/refraction studies of the continental lithosphere: a global review, Rev. Geophys., 25, 723-742.

Mooney, W. D. and R. Meissner, 1992, Multi-genetic origin of crustal reflectivity: a review of seismic reflection profiling of the continental lower crust and Moho, in "Continental Lower Crust", ed. by D. M. Fountain, R. Arculus and R. W. Kay, Elsevier, Amsterdam, 45--79.

Nakahara, H., T. Nishimura, H. Sato and M. Ohtake, 1998, Seismogram envelope inversion for the spatial distribution of high-frequency energy radiation from the earthquake fault: Application to the 1994 far east off Sanriku earthquake, Japan, J. Geophys. Res., 103, 855-867.

Nishigami, K., 1991, A new inversion method of coda waveforms to determine spatial distribution of coda scatterers in the crust and uppermost mantle, Geophys. Res. Lett., 18, 2225-2228.

Nishigami, K., 1997, Spatial distribution of coda scat- 
terers in the crust around two active volcanoes and one active fault system in central Japan: Inversion analysis of coda envelope, Phys. Earth Planet. Interiors, 104, 75-89.

Nishigami, K., 2000, Deep crustal heterogeneity along and around the San Andreas fault system in central California and its relation to the segmentation, J. Geophys. Res., 105, 7983-7998.

西上欽也, 2001, コーダ波エンベロープの解析による散 乱強度非一様分布の検出, 地震 $2,54,185-191$.

Nishimura, T., 1996, Horizontal layered structure with heterogeneity beneath continents and island arcs from particle orbits of long-period $\mathrm{P}$ waves, Geophys. J. Int., 127, 773-782.

Nishimura, T., M. Fehler, W. S. Baldridge, P. Roberts and L. Steck, 1997, Heterogeneous structure around the Jamez volcanic field, New Mexico, USA, as inferred from the envelope inversion of activeexperiment seismic data, Geophys. J. Int., 131, $667-681$.

西澤 修・雷 興林・チャダラム シバジ, 2001, 不均 質媒質での地震波伝播モデル実験, 地震 $2,54,171-$ 183.

Obara, K., 1989, Regional extent of the S wave reflector beneath the Kanto district, Japan, Geophys. Res. Lett., 16, 839-842.

Obara, K., 1997, Simulations of anomalous seimsogram envelopes at coda portions, Phys. Earth Planet. Interiors, 104, 109-125.

小原一成, 2001, S 波エンベロープ拡大現象, 地震 2 , 54, 159-170.

Obara, K. and H. Sato, 1988, Existence of an S wave reflector near the upper plane of the double seismic zone beneath the southern Kanto district, J. Geophys. Res., 93, 15037-15045.

O'Doherty, K. B., C. J. Bean and J. M. Closkey, 1997, Coda wave imaging of the Long Valley caldera using a spatial stacking technique, Geophys. Res. Lett., 24, 1547-1550.

Phillips, W. S., S. Kinoshita and H. Fujiwara, 1993, Basin-induced Love waves observed using the strong-motion array at Fuchu, Japan, Bull. Seism. Soc. Am., 83, 64-84.

Rautian, T. G. and V. I. Khalturin, 1978, The use of the coda for determination of the earthquake source spectrum, Bull. Seism. Soc. Am., 68, 923948.

Revenaugh, J., 1995a, The contribution of topographic scattering to teleseismic coda in Southern California, Geophys. Res. Lett., 22, 543-546.

Revenaugh, J., 1995b, A scattered-wave image of subduction beneath the Transverse Ranges, Science, 268, 1888-1892.

Ritter, J. R. R., S. A. Shapiro and B. Schechinger, 1998, Scattering parameters of the lithosphere below the Massif Central, France, from teleseismic wavefield records, Geophys. J. Int., 134, 187-198.
Roecker, S. W., B. Tucker, J. King and D. Hatzfeld, 1982, Estimates of $Q$ in central Asia as a function of frequency and depth using the coda of locally recorded earthquakes, Bull. Seism. Soc. Am., 72, 129-149.

Roth, M., 1997, Statistical interpretation of traveltime fluctuations, Phys. Earth Planet. Interiors, 104, 213-228.

Roth, M. and M. Korn, 1993, Single scattering theory versus numerical modelling in 2-D random media, Geophys. J. Int., 112, 124-140.

Rothert, E. and J. R. R. Ritter, 2000, Small-scale heterogeneities below the Gräfenberg array, Germany from seismic wavefield fluctuations of Hindu Kush events, Geophys. J. Int., 140, 175-184.

Ryberg, T. and F. Wenzel, 1999, High-frequency wave propagation in the uppermost mantle, J. Geophys. Res., 104, 10655-10666.

Ryberg, T., K. Fuchs, A. V. Egorkin and L. Solodilov, 1995, Observation of high-frequency teleseismic Pn on the long-range Quartz profile across northern Eurasia, J. Geophys. Res., 100, 18151-18163.

Ryberg, T., M. Tittgemeyer and F. Wenzel, 2000, Finite difference modelling of $\mathrm{P}$-wave scattering in the upper mantle, Geophys. J. Int., 141, 787-800.

Sato, H., 1977, Energy propagation including scattering effects: single isotropic scattering approximation, J. Phys. Earth, 25, 27-41.

Sato, H., 1978, Mean free path of S-waves under the Kanto district of Japan, J. Phys. Earth, 26, 185-198.

Sato, H., 1989, Broadening of seismogram envelopes in randomly inhomogeneous lithosphere based on the parabolic approximation: southeastern Honshu, Japan, J. Geophys. Res., 94, 17735-17747.

Sato, H., 1993, Energy transportation in one- and two-dimensional scattering media: analytic solutions of the multiple isotropic scattering model, Geophys. J. Int., 112, 141-146.

Sato, H., 1994, Multiple isotropic scattering model including $\mathrm{P}-\mathrm{S}$ conversions for the seismogram envelope formation, Geophys. J. Int., 117, 487-494.

Sato, H., 1995, Formulation of the multiple nonisotropic scattering process in $3-\mathrm{D}$ space on the basis of energy transport theory, Geophys. J. Int., 121, 523-531.

Sato, H. and M. C. Fehler, 1998, Seismic wave propagation and scattering in the heterogeneous Earth, Springer-Verlag, New York, 308 pp.

Scherbaum, F. and H. Sato, 1991, Inversion of full seismogram envelopes based on the parabolic approximation: Estimation of randomness and attenuation in southeast Honshu, Japan, J. Geophys. Res., 96, 2223-2232.

Shang, T. and L. Gao, 1988, Transportation theory of multiple scattering and its application to seismic coda waves of impulse source, Scientia Sinica (ser. B), 31, 1503-1514. 
Shapiro, S. A. and G. Kneib, 1993, Seismic attenuation by scattering: theory and numerical results, Geophys. J. Int., 114, 373-391.

Shapiro, S. A., R. Schwartz and N. Gold, 1996, The effect of random isotropic inhomogeneities on the phase velocity of seismic waves, Geophys. J. Int., 127, 783-794.

Shiomi, K., H. Sato and M. Ohtake, 1997, Broad-band power-law spectra of well-log data in Japan, Geophys. J. Int., 130, 57-64.

Singh, S. and R. B. Herrmann, 1983, Regionalization of crustal coda $Q$ in the continental United States, J. Geophys. Res., 88, 527-538.

Tittgemeyer, M., F. Wenzel, K. Fuchs and T. Ryberg, 1996, Wave propagation in a multiple-scattering upper mantle-observations and modelling, Geophys. J. Int., 127, 492-502.

Tittgemeyer, M., F. Wenzel, T. Ryberg and K. Fuchs, 1999, Scales of heterogeneities in the continental crust and upper mantle, Pure Appl. Geophys., 156, 29-52.

Tittgemeyer, M., F. Wenzel and K. Fuchs, 2000, On the nature of Pn, J. Geophys. Res., 105, 1617316180 .

Tsujiura, M., 1978, Spectral analysis of the coda waves from local earthquakes, Bull. Earthq. Res. Inst., 53, 1-48.

Wagner, G. S., 1996, Numerical simulations of wave propagation in heterogeneous wave guides with implications for regional wave propagation and the nature of lithospheric heterogeneity, Bull. Seism. Soc. Am., 86, 1200-1206.

Wagner, G. S., 1997, Regional wave propagation in southern California and Nevada: Observations from a three-component seismic array, J. Geophys. Res., 102, 8285-8311.

Wagner, G. S. and C. A. Langston, 1992, A numerical investigation of scattering effects for teleseismic plane wave propagation in a heterogeneous layer over homogeneous half-space, Geophys. J. Int., 110,
486-500.

Warner, M., 1990, Basalts, water, or shear zones in the lower continental crust?, Tectonophysics, 173, 163-174.

Wu, R.-S., 1985, Multiple scattering and energy transfer of seismic waves-separation of scattering effect from intrinsic attenuation-I. Theoretical modelling, Geophys. J. Roy. Astr. Soc., 82, 57-80.

Wu, R.-S. and K. Aki, 1988a, Introduction: Seismic wave scattering in three-dimensionally heterogeneous earth, Pure Appl. Geophys., 128, 1-6.

Wu, R.-S. and K. Aki, 1988b, Multiple scattering and energy transfer of seismic waves-Separation of scattering effect from intrinsic attenuation. II. Application of the theory to Hindu Kush region, Pure Appl. Geophys., 128, 49-80.

Wu, R.-S., Z. Xu and X.P. Li, 1994, Heterogeneity spectrum and scale-anisotropy in the upper crust revealed by the German Continental Deep-Drilling (KTB) Holes, Geophys. Res. Lett., 21, 911-914.

Yomogida, K., K. Aki and R. Benites, 1997, Coda $Q$ in two-layer random media, Geophys. J. Int., 128, 425433, 49-80.

吉本和生, 2001, ボルン近似による地震波散乱特性の評 価とそのコーダ波解析への適用, 地震 2, 54, 147-158.

Yoshimoto, K., H. Sato and M. Ohtake, 1997a, Threecomponent seismogram envelope synthesis in randomly imhomogeneous semi-infinite media based on the single scattering approximation, Phys. Earth Planet. Interiors, 104, 37-61.

Yoshimoto, K., H. Sato and M. Ohtake, 1997b, Shortwavelength crustal heterogeneities in the Nikko area, Central Japan, revealed from the threecomponent seismogram envelope analysis, Phys. Earth Planet. Interiors, 104, 63-73.

Zeng, Y., F. Su and K. Aki, 1991, Scattering wave energy propagation in a random isotropic scattering medium, 1. Theory, J. Geophys. Res., 96, 607619. 